\title{
Kamu Adaletinin Büyülk Veri Aracılığı ile İnşası: Şule Çet Davası Üzerine Bir Twitter Analizi
}

\section{Construction of Public Justice through Big Data: A Twitter Analysis of the Şule Çet Case}

\author{
Filiz YILDIZ $^{1}$, Onur DURSUN $^{1 \oplus}$
}

'Assoc. Prof. Dr., Çukurova University, Faculty of Communication, Department of Journalism, Adana, Turkey

ORCID: O.D. 0000-0001-9268-0936; F. Y. 0000-0002-1206-4314

Sorumlu yazar/Corresponding author: Onur Dursun,

Çukurova Üniversitesi, İletişim Fakültesi, Gazetecilik Bölümü, Adana, Türkiye,

E-posta/E-mail: odursun@cu.edu.tr

Geliş tarihi/Received: 20.01.2020 Revizyon talebi/Revision Requested: 20.02.2020

Son revizyon teslimi/Last revision received: 17.06 .2020

Kabul tarihi/Accepted: 19.06 .2020

Atıf/Citation: Yildiz, F., \& Dursun, O. (2020). Kamu adaletinin büyük veri aracılığı ile inşası: Şule Çet davası üzerine bir Twitter analizi. Connectist: Istanbul University Journal of Communication Sciences, 58, 291-328 https://doi.org/10.26650/CONNECTIST2020-0009
Öz

Bu çalışma, büyük veri temelli sosyal ağların özellikle de Twitter'ın toplumsal hareketlerde ve hak arama mücadelelerinde sunmuş olduğu fırsatlara odaklanmıştır. Twitter gibi sosyal medya ortamlarının ne ölçüde bir kamusal alan özelliği taşıdığını tartışan çalıșma, sivil/kamu adaletinin bu mecralarca sağlanabilme potansiyeline ışık tutmaya çalışmıştır. 29 Mayıs 2018 tarihinde gerçekleşen Şule Çet cinayetinin mahkeme sürecinin takibi için Twitter'da @ suleicinadalet kullanıcı adıyla açılan Şule Çet Dayanışma Platformu'nun tweetleri analize tabi tutulmuştur. Hesabın 1 Şubat 2019 - 31 Aralık 2019 tarihleri arasındaki tweet, retweet ve fav hareketliliği incelenerek görselleştirilmiştir. İkinci aşamada ise yine bu hesabın 01 Eylül - 31 Aralık 2019 tarihleri arasındaki 783 tweeti, çeşitli kategoriler altında nicel içerik analizine tabi tutulmuştur. Çalışma, Twitter gibi sosyal ağların, kamusal alan olma ve kamusal topluluğu iletişime/etkileşime geçirebilme ve örgütleyebilme yolunda önemli olanaklar yarattığını; sosyal ağlar üzerinden örgütlenen kamusal toplulukların sivil/kamu vicdanı/adaleti aracılığılla resmi/yasal adaletin sağlanmasına katkı yapma potansiyeli taşıyabildiğini göstermiştir. Sosyal ağların, dezavantajlı konumda olan kesimlerin sesi olabildiğini ve uğradıkları adaletsizlik karşısında hak mücadelesine girebildiklerini ve başarılı olabildiklerini ortaya koymuştur. Çalışmada sosyal ağlara, sorunlu yanları irdelenmekle birlikte, genel anlamda bir olanak olarak yaklaşılmıştır.

Anahtar Kelimeler: Şule Çet cinayeti, sosyal medya, Twitter, yarı kamusal alan, sivil kamu vicdanı adaleti

\section{ABSTRACT}

This study focuses on the opportunities provided by social networks based on Big Data, specifically Twitter, for social movements and rights struggles. Discussing to what extent social media environments like Twitter act as a public sphere, this 
study tried to shed light on the potential of these channels to provide civil/public justice. Tweets from the Şule Çet İçin Adalet Platform created by the username @suleicinadalet in order to follow the trial of the Şule Çet murder on May 29, 2018 were subjected to analysis. The tweet, retweet and favourite counts of the account between February 1st, 2019 and December 31st, 2019 were examined and visualised. In the second stage of the study, 783 tweets from this account between September 1st and December 31st, 2019 were subjected to quantitative content analysis under various categories. Social networks like Twitter create crucial opportunities as a public sphere, and public communities within this public sphere can communicate/interact and organise via social networks. In the study, it is seen that public communities organised on social networks can lead to secure legal justice through civil/public conscience/ justice. At the same time, the study revealed that social networks can be the voice of disadvantaged people/ groups, and that they can fight for rights and succeed in the face of injustice. In this study, social networks were approached as an opportunity in general terms, although their problematic aspects were scrutinised.

Keywords: Şule Çet murder, social media, Twitter, semi-public sphere, civil public conscience justice

\section{EXTENDED ABSTRACT}

A public sphere can be defined as an abstract space where public communities can express opinions on public issues and thus create an agenda in relation to those issues, as a result of which they can affect the decision making processes either positively or negatively. Habermas defines the public space/sphere as a kind of space formed by individuals coming together that enables interaction among members of the public community. The primary function of this community is to contribute to the establishment of mechanisms enabling the formal administrative operations of the public space which is the common ground for living, or to intervene in the formation of public decisions through public judgement and argumentation.

The media has foregrounded the concept of a new public space. Even though social networks do not typically bear all the characteristics of the public sphere in Hebermesian terms, they have shown significant improvements in this regard. Accordingly, internetbased social networks were conceptualised as a semi-public sphere in this study, and discussed upon theoretical grounds.

Accordingly, this research sets out to investigate how the civil or public notion of justice / conscience may be established/shaped through social media, or the so termed semi-public sphere, with specific reference to the data obtained from the judicial processes of the death of a young woman named, Şule Çet, in Ankara, on May 29th, 2018. Her death was initially claimed to be caused by suicide, whereas 
eventually it was argued to be the result of murder. The young woman was reported to be thrown off the 20th. floor of a tall building. The event itself and related judicial processes aroused strong public attention; for instance, a Solidarity Platform was formed for this purpose. The data in the study basically consists of tweets and retweets regarding the judiciary processes, obtained from the account of the Şule Çet Solidarity Platform. More specifically, the course and content of the tweeting and re-tweeting traffic, covering the 11-month period between February, 1st, and December, 31st, 2019 - approximately marked by the dates when the first court case was opened and ended by the announcement of the reasoned decision, were analysed. Twitter API (Application Programming Interface) was employed while obtaining the digital data and the R studio application was used as a concordant programming tool. Also Workbench and Excel programs were used.

3070 tweets were gathered for the purpose of this study from the Twitter account namely @suleicinadalet; however, since the given tweets were retweeted 840,120 times, the total tweet track accumulated up to $2,573,206$. It was observed that while 186,666 favs were received along with the tweets on the date of the first court case, this number rose up to 312,875 on December the 4th 2019, the date when the verdict was announced. During the whole judicial process various hashtags such as \#Şuleçetiçinadalet (justice for şule çet), \#ŞuleÇetinSesiOl (Be the Voice of Şule), \#ŞuleÇet, \#Susma (do not be quiet), \#4Aralık'taŞuleÇetDavasındayız (we will be in Şule Çet course on December, 4th.) were created by different civil initiatives: such as women's organisations, lawyers, politicians, academics, and well recognised figures in society that tweeted numerous encouraging, messages, expressing their hopes and hearty beliefs for the realisation of justice, and towards creating public awareness. Findings of the study have revealed that quantitatively speaking, intensity patterns of the relevant tweets coincided with important dates of the judicial processes and with significant events related to the issue.

Quantitative content analysis was also applied to the 783 tweets for the 4-month period between September, 1st, and December, 31st, 2019, and evaluated under various categories. Investigated in this study was the question, to what extent did the topics of the tweets between September, 1st, 2019 and December, 31st, 2019, relate directly to the judicial process of Şule Çet. It was observed that of the 783 tweets, $64.08 \%$ $(n=512)$ directly related to the Şule Çet case, $34.29 \%(n=274)$ were about relevant topics and $1.63 \%(n=13)$ were categorised as 'others.' 
Findings of the study have also revealed that the concept of 'justice' was used as the underlying theme of 783 tweets, in various contexts; namely, $67.18 \%$ were 'call for justice', 12.95\% emphasised 'injustice', 12.18\% 'hope for justice', 3.95\% 'establishment of justice' and $3.73 \%$ were about other aspects of justice.

It is also noteworthy that the tweets of the Şule Çet Solidarity Platform, were not only limited to the given court case, but also expanded to a broader span for the search of rights in the general sense. Specifically, $70.28 \%$ of the tweets related to relevant topics ( $n=274$ ) dealt with women's murder, 13.29\% violence against women, 5.59\% sexual abuse, $4.20 \%$ children's murder, $3.50 \%$ men's murder, $2.80 \%$ child abuse and $0.35 \%$ missing persons.

It may be concluded that internet based social networks, which are conceptualised as being semi-public spaces in this study, might provide women and people in general, with certain opportunities with regard to both social and legal practices by enabling the contribution of public judgement towards establishing better public decisions and administrative mechanisms. 


\section{GíRiş}

Şule Çet'in Katili Çağatay Aksu: Halk ve sosyal medya baskısı yüzünden tutuklandık (Öztürk, 2019).

Sanık avukatı "Sosyal medyada \#ŞuleÇetiçinAdalet diye hashtag açmışlar binlerce tweet atmışlar. O yüzden bu duruşma salonu bu kadar kalabalık. Şimdi telefonuma baktım şu an mahkemeden bile canlı yayın yapıyorlar" diyerek mahkemenin sosyal medya baskısından etkileneceğini söyledi. Hâkimler sanık avukatlarına tepki gösterdi. \#ŞuleÇetiçinAdalet etiketinden şikâyetçi oldu ("Şule Çet davasında...," 2019).

Habermas (2001, p. 389), Iletişimsel Eylem Kuramı́nda yapıların kendi içinde iyi ve kötü yanı birlikte barındırdığını iletişim araçları üzerinden dile getirir. Günümüz toplumlarının enformasyon akışını sağlayan kitle iletişim araçları, mülkiyet yapıları ve ticari ilişkileri bakımından tartışmalara oldukça açık olsa da (Adaklı, 2006; 2010; Bek, 2010; Dursun, 2012; Kuyucu, 2013, 2014; Kadıŏlu, 2018), toplumun sesi olması ve yönetim mekanizmaları üzerinde baskı kurabilmesi açısından oldukça önemlidirler. Gerek ulusal düzeyde gerekse uluslararası düzeyde etkinlik gösteren medya şirketleri, ticari bir mantıkla çalışmaktadırlar. Geleneksel kitle iletişim araçlarının sorunlu mülkiyet yapıları, devletle ya da siyasal iktidarla olan sorunlu ilişkileri sayısız çalışmaya konu olmuştur (Djankov et al., 2003; Pickard, 2015; Noam, 2016).

Günümüzde geleneksel iletişim araçlarından daha etkili olan, toplumların ya da dünyanın gündeminin oluşmasına aracılık eden dijital medya ortamlarının mülkiyet yapıları, devletlerle ve siyasal erklerle olan ilişkileri de yine bir o kadar tartışmaya muhtaçtır, ki tartışılmaktadır da (Hurlburt, 2012; Atabek, 2013; Bulut, 2015). Her şey bir yana, dijital platformlar Silikon Vadisi'nin ürünleridir. Başka bir anlatımla ABD menşeili şirketlerdir ve uluslararası alanda oldukça etkili ve dünyanın da sayılı şirketleri arasında yer almaktadırlar (Okerson, 1996; Carveth, 2004; Lawson-Borders, 2003). Büyük verinin toplandığı ve depolandığı dijital ortamların tümü, küresel şirketlerin denetimindedir (Al-Khouri, 2012; Hoeren, 2014; Guo, \& Vargo, 2015). Bu açıdan, dijital ortamlar, yani Google, Youtube, Facebook, Twitter, Instagram gibi dijital paylaşım mecraları, küreselkapitalist bağlamda incelenmekte ve tartışılmaktadır (Fuchs, 2014, pp. 58-59; 2018, pp. 133-166; Baran et al., 2015, Narin et al., 2017). Ama bu, ilgili paylaşım ortamlarının iyi şeylere sebep olmadığı anlamına gelmemelidir. Habermasçı düşünceyle olaya yaklaşacak olursak, ticari ve mülkiyet yapılarını bir kenara bıraktığımızda, bu mecraların, toplumsal 
grupların etkileşime girebilmesine yardımcı olduğunu (Cottle, 2011, p. 651), devletler, siyasal ve yönetici güçler üzerinde baskı kurabilme potansiyeli taşıdığını, dijital aktivizm bağlamında politika üretiminde etkili olduğunu, katılımı daha da arttırdığını (Kahn, \& Kellner, 2004; Çildan et al., 2012; Karagöz, 2013) dile getirmemiz yanlış olmayacaktır.

Burada dikkat edilmesi gereken nokta, bir yapının ya da aracın her iki potansiyelinin de farkına varabilmektir. Büyük veri, büyük şirketlerde toplandığı için, her an halkın lehinde ya da aleyhinde kullanılabilme özelliği taşımaktadır. Bu, WikiLeaks ve Panama Belgeleri olaylarında açıkça görülmüştür. İnsanların ya da kurumların/yapıların mahrem ya da gizli bilgileri izinsiz bir şekilde kamuya açılmıştır. Dünya genelinde bazı konular hakkında olumlu anlamda birtakım farkındalıklar yaratılmış olsa da mahrem alanın kamusallaştııılması ya da gizli bilgilerin yayılması açısından eleştiri de almıştır. Büyük veriyi toplayan, depolayan ve yönetenlerin amacı ve hedefi her zaman önemlidir. Hangi bilgiyi, ne zaman, nasıl ve neden kullandığı tartışmaların başladığı asıl noktadır. Büyük veriyi de her iki açıdan, yani hem olumlu hem de olumsuz anlamda ele almak gerekir. boyd ve Crawford, diğer sosyo-teknik olgular gibi büyük verinin de hem ütopyacı hem de distopyacı söylemler içerdiğini belirtirler. Büyük verinin bir yandan çeşitli toplumsal hastalıkları ele almak için güçlü bir araç olarak göründüğüne ve kanser araştırması, terörizm ve iklim değişikliği gibi çeşitli alanlara yeni bakış açıları kazandırma potansiyeli taşıdığında dikkat çekerler. Diğer yandan da büyük verinin, gizliliği ihlal ederek, sivil özgürlüğü olumsuz yönde etkileyerek, devlet ve şirket kontrolünü arttırarak Büyük Birader'in rahatsız edici bir tezahürü olarak görünebileceğini dile getirirler. body ve Crawford'a göre, bütün sosyo-teknik olgularda olduğu gibi, umut ve korku akışı, sürekli olarak devam etmekte olan daha ince ve kurnaz dönüşümleri de gizil hale getirir (boyd, \& Crawford, 2012, pp. 663-664).

Büyük verinin depolandığı ve mobilize olduğu dijital paylaşım mecraları, yani sosyal medya ortamları barındırdıkları ikilemlerle yaşamı yönlendirmeyi, ve toplumların gündeminin oluşmasına aracılık etmeyi sürdürmektedirler. Bu ortamlar sessizlerin sesi olması, Jenkins'in (2016, p. 428) ifadesiyle hem "Teknoloji yerine kültürel ve sosyal protokollerle şekillenen izleyici uğraşı" biçimindeki katıımı hem de "Hayranların ve diğer tüketicilerin yeni içeriğin üretimine ve dağıtımına aktif olarak katılmaya davet edildikleri kültür" olarak katılımcı kültürü beslemesi, dezavantajlı gruplara temsil şansı tanıması ve en önemlisi de tüketici konumunda olanların üretim sürecinde de dâhil olabilmesi (Jenkins, pp. 199-220) bağlamında bir olanaktır. Fakat Sandoval ve Fuchs (2015), bu tür araçların kapitalist üretim ve tüketim ilişkileri barındırmasından, sınırlı 
sayıda belirli zümrelerin erişimine açık olmalarından, teknik anlamda kullanım becerisi eşitsizliği yaratmalarından dolayı karşıt bir görüş ileri sürerler (English, 2013, pp. 152153). Dijital medya ortamları, iktidarın denetiminde olmaları, başka bir ifadeyle ilgili mecralara ilişkin düzenlemelerin ve denetimlerin siyasal iktidarlarca gerçekleştiriliyor olması açısından yine sorunludur ve gelenekselde olduğu gibi denetim altına alınabilme potansiyelini her zaman taşımaktadırlar. Bunlara rağmen, geleneksel medya ortamlarına oranla daha özgür, daha çoğulcu ve daha demokratik olma özelliği göstermektedirler (Khondker, 2011). Bu düşünce, Yeni Medya Çalışmaları IV. Ulusal Kongresi'nde de üzerinde durulan bir nokta olmuştur. Kongrenin Sonuç Bildirgesi'nde önemli noktalara değinilmiştir: Yeni iletişim teknolojilerinin katılımı/katılımcı kültürü özendirdiği, alternatif medya araçlarının görece iktidardan bağımsız olmayı başarabildikleri ama iktidarın bu oluşumları denetim altına almaya çalıştığı ve kısmen de başarıya ulaştığı; geleneksel iletişim araçlarıyla kendilerini görünür kılamayan dezavantajlı grupların sosyal medya sayesinde sınırlı da olsa görünür hale gelebildiği; yeni medya ortamlarının, birçok grubu ağlar üzerinden örgütlü hale getirebildiği; çeşitli ihlallere uğrayan göçmenlerin, mültecilerin ve sığınmacıların da yine ağlar üzerinden birbirleriyle ve yerel halkla ilişki kurabildiği sonuçlarına varıımıştır (YMK4, 2019).

Dijital medya, yeni kamusal alan kavramını gündeme taşımıştır. İnternet tabanlı sosyal medya ortamlarının kamusal alan niteliği taşıyıp taşımadığı, ne derecede demokrasiyi özendirdiği ve katılıma izin verdiği gibi bağlamlarda tartışmalar devam etmektedir (Papacharissi, 2002; Anderson, 2003; Downey, \& Fenton; 2003; Gerhards, \& Schäfer, 2010; Bayraktutan et al., 2011; Karataş, \& Binark, 2016; Çalışkan, 2014). Sosyal ağlar, Habermasçı anlamda tümüyle bir kamusal alan özelliği gösteremese de bu doğrultuda önemli gelişmeler kaydetmiştir. Habermas'ın (2009, pp. 17-18), 'kamu'nun izleyici ve dinleyicilerden değil, birbirlerine karşılıklı sorular soran ve ilgili soruları yanıtlayanlardan oluşan bir uzam'şeklindeki düşüncesi, bu uzama kamusal alan özelliği yükler görünmektedir. Ama yine Habermas'ın (1974, pp. 40-50), 'kamusal alanın en büyük özelliğinin aleniyete dayanması, kamusal alanı paylaşan herkesin bu alana hiçbir engele takılmadan dâhil olabilmesi, yani kamusal alanın herkese garanti edilmiş olması' gibi düşünceleri dikkate alındığında ise sosyal ağların bu bağlamda eksik kalması, bu uzamın kamusal alan olma özelliğine gölge düşürür gibidir. Çünkü internet erişimi, kullanım becerisi, internet üzerindeki ticari ve siyasi baskılar ya da sosyal ağların doğrudan küresel şirketlerin birer ürünü olması, bu uzamın kamusal alan olma özelliğini tartışmalı hale getirmektedir. Illaveten sosyal ağlarda özel şahısların sanal kimliklerle kendilerini sunmaları da yine Habermasçı kamusal alanın aleniyet ilkesine uymamaktadır. Bu 
yüzden bu çalışmada, internet tabanlı sosyal ağlar, yarı kamusal alan olarak nitelendirilmiştir. Ardından çalışmanın temel konusu olan sivil/kamu adaletinin yarı kamusal alan olarak kavramsallaştırdığımız sosyal medya aracıyla nasıl tesis edildiği Şule Çet Davası süreci üzerinden somutlaştırılarak, sosyal medya bir olanak olarak irdelenecektir.

\section{Kamusal Alan ve Yeni Medya}

Bentham, aynı doğrultuda düşüncelere sahip topluluğun, tüm mahkemelerden daha değerli bir mahkeme olduğunu belirtir. Bentham, insanın, bu mahkemeyi hiçe sayıyormuş gibi yapabileceğini ama herkesin bu mahkemenin, yanılma ihtimali olsa da, satın alınamayacağını; daima kendini aydınlatmaya uğraştığını; halkın bilgelik ve adaletini kendi içinde topladığını; devlet yöneticilerinin kaderinin bu mahkemece belirlendiğini ve bu mahkemenin verdiği cezadan kurtuluşun mümkün olmadığını hissettiğini belirtir. Bentham'a göre, kamuoyunun egemenliğinde artık hiçbir şey daha kolay değildir. Aleni meclisleri bulunan bir halkın birliktelik ruhunun daha yüksek bir noktadan cereyan edeceğini ifade eden Bentham, böylesi bir ortamda sağlıklı fikirlerin daha yaygın hale geleceğini ve zararlı önyargıların ise gücünü kaybedeceğini düşünür (as cited in Habermas, 2009, pp. 197-198). Bentham'ın bu betimlemesi, kuşkusuz kamusal alanda bir araya gelen kamusal topluluğun gücüne işaret eder. Hatta Rawls'ın (2018, p. 78), “En yüksek başvuru mercii, yasama, yürütme ya da yargı değil kamuoyudur.” ifadesi kamunun gücüne tekrardan vurgu yapar. Peki, kamusal alandan ve kamusal topluluktan ya da kamuoyundan ne anlaşılmalıdır?

Kamusal alanı, kamusal toplulukların kamusal meseleler üzerinde akıl yürüttükleri ve böylece ilgili kamusal meselelere ilişkin kamuoyu oluşturdukları ve nihayetinde kararların alınmasına ya da alınmamasına etki ettikleri soyut bir uzam olarak tanımlamak mümkündür. Habermas, kamusal alanı, özel şahısların bir araya gelerek oluşturduğu kamusal topluluğun iletişime/etkileşime geçebildiği uzam olarak nitelendirir. Bu topluluğun temel işlevi, ortak yaşam alanı olan kamusal alanın yönetimsel olarak yapısal işleyişini sağlayacak mekanizmaların şekillenmesine ya da kamusal kararların oluşmasına kamusal akıl yürütme, yani usavurum/muhakeme etme yoluyla müdahale etmektir (Habermas, 2009, p. 93). Bu açıdan, kamusal alan, kamusal topluluğun özellikle de düşünsel anlamda etkinlik göstererek devlet ya da siyasal erk üzerinde etkide bulunduğu bir uzamdır. Habermas'ın düşüncesinde 'kamusal', kapalı toplantılar hariç herkese açık olan toplantılardır. Habermas'a göre, devlet 'kamusal erk'; halkın kendisi'kamuoyu'; kamuoyunun eleştirel işlevi ise aleniyeti sağlamaktır. 
Bu aleniyeti de halkla ilişkiler gibi 'kamuoyu çalışmaları' sağlamakla mükelleftir. Devletin kurumları ve konumuzla bağlantııı olan medya da 'kamusal organlar' olarak karşımıza çıkmaktadır (Habermas, 2009, pp. 57-59).

Habermas, kamusal alanın izlerini 17. yüzyılda bulur. Eleştirel tartışmaların başladığı kamusal topluluk ilk kez Almanya'da belirginleşmiştir. Bu topluluğun oluşmasını ise, burjuva ve şehirli vatandaşlar dışındaki insanların, yavaş yavaş basılı eserleri okuyabilme yeteneği edinmeye başlaması sağlamıştır. Böylece okur kitleleri oluşmaya ve düzenli okuma pratiği alışkanlık olarak yerleşmeye başlamıştır. Nihayetinde özel alan içinden doğan ve bu alandan kopmaya yüz tutan kamusal bir iletişim topluluğu kendisini yavaştan göstermiştir. Bu topluluğun gelişmesine ise hızla yükselen okuyucu sayısı; buna bağlı olarak artan gazete ve kitap sayısı ve yine bunların sonucu olarak artan yazar ve yayınevi sayısı neden olmuştur (Habermas, 2009, p. 16). Habermas, radyo gibi kitle iletişim araçlarının, içerik olarak önceden kurgulanmasından kaynaklı olarak, kamusal bir akıl yürütme ortamı olamayacağını, yani siyasal üzerinde etki kuramayacağını belirtir. Ona göre kitle iletişim araçlarıyla şekillendirilen yeni dünya, sadece görünüşte kamusaldır; akıl yürüten kamusal topluluk kitle iletişim araçlarıyla şekillendirilen yeni dünyanın tüketicilerine dönüşmüştür (Habermas, 2009, pp. 286, 295). Bu süreç, Habermas'ın, kamusal alanın yapısal dönüşümü olarak nitelendirdiği durumdur. Kamusal akıl yürütmenin araçları olan iletişim araçları, 19. yüzyılda kapitalizmin baş göstermesiyle şirketleşmeye ya da şirketlerin eline geçmeye başlamıştır. Illetişimsel eylemin döngüsünü sağlayan bu araçlar, ticarileştikleri için, amaçlarından sapma göstermiştir. Kamusal alandaki kamusal topluluğun birbiriyle iletişime geçtiği araçlar, ticarileşince, ilk dönemlerdeki özelliklerini kaybetmişlerdir. Artık bu araçlardan sağlıklı bir kamuoyu oluşturmaları beklenemez hale gelmiştir. Bu süreç, yani medyanın ticarileşmesi günümüze kadar devam etmiştir.

Tüm medya organları, holdinglerin eline geçtiğinden, halkın sesi olmak ya da kamuoyunun, kamudan yana şekillenmesinden ziyade güç merkezlerince şekillenmesine neden olarak, kendilerinden beklenenin aksine işlem görür olmuşlardır. Fakat günümüzdeki sosyal medya ortamları, ticari olmakla birlikte, siyasal güç merkezlerinden daha ziyade halkın sesi olmayı başarabilmiştir. Bu açıdan aslında kamusal alan tekrardan yapısal bir dönüşüme uğramıştır. Sosyal medya ticari ama daha çok halktan yana, halkı tüketici olarak görmekle birlikte üretici olarak da konumlandırarak, geleneksel iletişim araçlarından kendisini farklılaştırmayı başarmıştır. Sosyal medyanın kamusal alan olarak nitelendirilmesinin temel nedeni kuşkusuz budur. Sosyal ortamlar, büyük kitlelerin fikir 
alışverişine girebilmesine olanak tanımaktadır. Geleneksel araçların oldukça sınırlı biçimde olanak tanıdığı katılımın ve etkileşimin boyutunu olabildikçe genişletebilmiş ve böylece de karar alma süreçlerinde devlet ve siyasal erk üzerindeki baskıyı arttırabilmiştir (Cottle, 2011; Ghannam, 2011).

\section{Sosyal Medya ve Sivil/Kamu Adaleti}

Kamu Vicdanına Çağrı: Sivil İtaatsizlik (Coşar, 2018) adlı kitap, sivil itaatsizlik kavramını sorgularken bireysel vicdanların toplamından oluşan kamu vicdanının işleyişini irdeler. Kitapta Coşar (2018, pp. 12-13), sivil itaatsizliğin genel olarak bir çağrı ve gönderilen bir mesaj olduğunu belirtir ve bu çağrının, ortak yani kamusal bir adalet anlayışından hareket ettiğini söyler. Sivil itaatsizliği Thoreau, Rawls, Arendt, Habermas, Dworkin, Saner, King ve Galtung gibi sosyal bilimcilerin düşünceleri bağlamında ortaya koymaya çalışan kitap, sivil itaatsizliği, yasal-anayasal sınırların dışına taşmaksızın azınlıkların ya da dezavantajlı grupların, yasama, yürütme ve yargı mercilerinde egemene karşı, herhangi bir şiddete başvurmadan, giriştikleri bir hak arama mücadelesi olarak temellendirir (Rawls, 2018, pp. 60-61; Habermas, 2018, p. 123). Sivil itaatsizlik, çağrısını kamuya, kamunun nesnel vicdanına yaparak yönetim üzerinde ya da kendi hakkını ihlal eden yasa üzerinde bir baskı kurmaya girişerek adaleti sağlamaya çalışır.

Burada nesnel vicdan ifadesini kullanma nedenimiz, Arendt'in, tarihin farklı dönemlerinde vicdanın bireysel benlikle de ilişkili biçimde kavrandığını anımsatıyor olmasından kaynaklanmaktadır. Arendt (2018, pp. 90-91), "metafizik olarak tanımlamadığımız sürece vicdanın, insanın sadece doğuştan getirdiği haklıyı haksızdan ayırma yeteneğini değil, ayrıca insanın kendi benliğine ilgisini de gerektirmesidir; çünkü belli bir şekilde davranma sorumluluğu sadece insanın kendi benliğine olan bu ilgisinden ortaya çıkar" şeklinde yazmaktadır. Arendt'e göre $(2018$, p. 91$)$ vicdanın sesi, doğal ışık haline gelerek insanüstü bir yasaya ilişkin bilgi vermeden önce Tanıının sesiydi, Tanrının kurallarını bizlere sunuyordu. Ama bu düşünce toplumların modernleşmesiyle birlikte dönüşmeye başladı ve dünyevileşti. Vicdan artık kuvvetini bireyselliğinden ya da Tanrısallığından değil kamusal ortaklıktan almaya başladı. Başka bir söylemle, bireysel vicdanların toplamından bir kamu vicdanı doğdu. Çünkü Arendt'e göre, bireysel vicdan, birey üzerinde bir baskı kurabiliyor ama başkaları üzerinde bir etki yaratmıyordu. Bireysel vicdanın etkili olabilmesi için, politikleşmesi gerekiyordu ve bu da ancak bir dizi insan vicdanının aynı kanaate ulaşarak, kamuya gitmesiyle ve sesini duyurmasıyla mümkündü (Arendt, 2018, p. 93). 
Bu nokta, çalışmamız açısından oldukça önem taşımaktadır. Çünkü sivil adalet ya da kamu adaleti dediğimiz durum, büyük ölçüde sivil itaatsizlik kapsamına da girmektedir. Bu çalışmada örnek olarak ele aldığımız olay, yasanın uygulamada gecikmesinin bir sonucu olarak ortaya çıkmış ve kamu vicdanı, sivil itaatsizlik bağlamında değerlendirilebilecek biçimde işleyerek yasayı değiştirmese de yasanın adilane biçimde uygulanışında etkili olmuştur. Dezavantajlı bir grup, yasayı kendi lehlerinde işletmeyi başarabilmiştir. Fakat bu türden örneklerle karşılaşmak her zaman mümkün değildir. Sivilin, adaleti tesis edebilmesi için birçok koşulun sağlanması gerekmektedir. Örneğin kamunun bir konuya itiraz edebileceği bir ortamın mevcudiyeti şarttır. Yani kamu, öncelikle tümüyle güvence altına alınmış bir ortamda bir araya gelebilmeli ve sesini duyurabilmelidir. Buna hiçbir güç engel olmamalı ve hatta desteklenmelidir. Lakin günümüz dünyasının siyasi ve iktisadi ikliminde bu türden girişimler geleneksel yöntemler açısından giderek güçleşmiştir. Özellikle demokrasisi sorunlu toplumlarda hak arayışları, siyasi ve iktisadi güçlerden görece bağımsız yeni/sosyal medya ortamlarına taşınmıştır. Fakat bu yeni ortamların da tümüyle sorunsuz olduğunu söylemek olanaklı görünmemektedir.

Medyanın, yasama, yürütme ve yargıdan sonra dördüncü güç olarak, kendisinden önceki güçleri denetleyebilecek güce sahip olduğu teorisi, demokratik açıdan gelişimini tamamlayamamış toplumlar için pek mümkün olamamaktadır. Desteğini, iktisadi ve siyasi mekanizmalardan değil de halktan alan bir medya ancak bu tür bir görevi yerine getirebilir. Kendisinden önceki güçlere bir şekilde bağlı olan medya kuruluşlarının, bu güçleri, halk adına, hakkıyla denetlemesi zordur. Bunun için sermaye çevrelerinden bağımsız, kendi sermayesini yaratabilen medya kuruluşlarına gereksinim vardır. Geleneksel medya kuruluşları, gelişmekte olan ülkelerde siyasal erk ve iktisadi sermaye ile yakın ilişkiler içerisindedir. Bu da, kendilerinden bekleneni yerine getirmemelerinin ya da getirememelerinin temel nedenidir.

Fakat aynı şeyleri sosyal medya ortamları için söylemek hem mümkündür hem de değildir. Kuşkusuz yukarıda da değindiğimiz gibi, sosyal medya ortamları, ticari kuruluşlardır. Fakat sermaye olarak doğrudan bir ülkeye ya da bir topluluğa bağlı değillerdir. Kendilerini var edecek ve yeniden üretecek koşulları kendileri yaratabilmektedirler. Her ne kadar ABD menşeili şirketler olsalar da gelirlerinin kaynağı küresel düzlemin kendisidir. Bu açıdan, ulusal medya şirketlerine ya da geleneksel medya organizasyonlarına oranla daha bağımsızdırlar. Medyanın unuttuğu ya da yerine getiremediği dördüncü güç özelliğini yerine getirme konusunda daha başarılıdırlar. 
Çünkü sosyal medya ortamları, halka içerik sunmaktan daha ziyade içeriğin oluşabileceği bir ortam sunarak, beşinci gücün yani kamunun devreye girmesine ve kendi içeriğini üretmesine olanak sağlamaktadırlar. Başka bir anlatımla, kamusal alanı paylaşan kamusal topluluğun iletişime/etkileşime girmesini, mücadele edebilmesini, olaylara tepki gösterebilmesini ya da taleplerini dile getirebilmesini, geleneksel medya araçlarına göre daha fazla sağlayacak iletişim kanalları oluşturabilmektedirler (Loader, 2008, pp. 1930-1931). Kamusal topluluğa zaman ve mekân olarak görece daha esneklik tanıyan sosyal medya, kamusal topluluğun sesini daha kısa bir zaman diliminde, daha geniş çevrelere yayabilmektedir. Böylelikle de olaylara ilişkin kamuoyunun hızlı bir biçimde ve genel olarak da kamunun istediği biçimde şekillenmesini sağlama yeteneği sergileyebilmektedir. Başka bir deyişle sivil adaleti yani kamu adaletini işletme konusunda önemli bir olanak sağlamaktadır.

Kahn ve Kellner (2004, p. 88), küresel düzlemde etkinlik gösterme özelliğine sahip internetin, terörizm, savaş ve yoğun siyasi mücadele dönemlerinde dünya çapında eşsiz bir savaş karşıtlığının, barış ve sosyal adalet hareketinin temelini oluşturabildiğinden söz ederler. Loader (2008, p. 1930) ise yeni medyanın, aktivist dijital yaratımları ve ana akım medya kuruluşlarını giderek daha fazla parçalayabilecek yorumlayıcı çerçeveleme ve kimlik politikaları için etkileşimli iletişim kanalları sunduğunu dile getirmektedir. Twitter, kendisinin, kullanıcıların kim olduğuna dikkat etmeksizin özgürce etkileşime girdiği tarafsız bir platform olduğu kanısındadır. Bu açıdan Twitter, toplumsal hareketlerde ilk bakışta "tarafsız bir araç" olduğunu kanıtlayarak, hükümetlerin ve haber organlarının gücüne meydan okuyabilmiş ve halkın "iletişim ve propaganda” aracı görevi üstlenmiştir (van Dijck, 2013, pp. 68-70). Bu, İran Olayları (2009), Arap Baharı (2010) ve İ̧gal Hareketi (2011) süreçlerinde kullanıcılarına önemli ölçüde yardım etmiştir. Aynı durum 2013 yılında Gezi Parkı sürecinde de yaşanmıştır (Özsoy, 2014; Sallan Gül et al., 2015; Filibeli, 2016). Sosyal ağlar üzerinden bir araya gelen kamusal topluluk, taleplerini ilgili mekanizmalara iletme başarısı göstermiştir. Social Media in the Arab World başlıklı raporda Ghannam (2011, p. 4), sosyal ağların bilgilendirici, harekete geçirici, eğlendirici, topluluklar oluşturucu, şeffafığı arttırarak hükümetleri hesap verebilir hale getirici yanlarına dikkat çekmiştir. Ghannam, Arap sosyal medya sitelerini, bloglarını, çevrimiçi videolarını ve diğer dijital platformlarını incelemenin çağdaş Arap tarihinde ifade, örgütlenme ve bilgiye erişim özgürlüğünde tartışmasız en önemli ve benzeri görülmemiş gelişmeye şahitlik etmek anlamına geldiğini söylemektedir. 
Sosyal ağlar, adalet arayışında ya da kamusal adaletin tesis edilmesinde de önemli bir konuma sahiptirler. Toplumsal hareketlerde ya da münferit hak arayışlarında, konunun gündeme taşınma anını kısaltarak, olayın mekânını olabildiğince genişleterek ve hatta ulus ötesine taşıyarak, ilgili mercilerin görevini daha hızlı ve daha adil bir şekilde yerine getirmesini sağlayacak gündemi oluşturabilmekte ve böylece de adaletin sağlanmasına öncülük edebilmektedirler. Çalışmanın takip eden analiz bölümünde, sivil/kamu adaletinin/vicdanının, resmi adaleti ya da kamu düzenini tesis etme potansiyeli Şule Çet Davası süreci üzerinden somutlaştırılmaya çalışılmıştır.

\section{AMAÇ VE YÖNTEM}

Çalışmada, sosyal medyanın örnek bir olay üzerinden hak arama mücadelesi sivil/ kamu adaletinin sağlanmasındaki etkisini ortaya koyabilmek amacıyla erişilebilen Büyük veri, nicel içerik analizi yaklaşımıyla incelenmiştir. Bu amaçla, adaletin tesisi, adaletsizlik vurgusu, adalet umudu ve adalet çağrısı şeklinde ana kategoriler oluşturulmuş ve elde edilen veriler betimsel analiz yöntemiyle irdelenmiştir.

\section{Amaç}

Çalışma, hak arayışlarında, büyük verinin toplandığı ve depolandığı sosyal medya ortamlarının etkisini ortaya koymayı amaçlamıştır. Kuşkusuz bu doğrultuda çok sayıda çalışma yapılımışı ır ve hala da yapılmaktadır. Ancak bu çalışmada büyük verinin tüm dönemlerde toplumların temel sorunlarından olan dezavantajı gruplara bir olanak sunup sunmadığı sorusundan hareket edilmiş̧ir. Oluşan yeni ve henüz yarı kamusal alanın dezavantajı grupların örgütlenmesine, hak mücadelesine girmesine, kendilerini daha görünür kılmalarına fırsat tanıyıp tanımadığına odaklanılmıştır. Bu çalışma, kadınların hak arama mücadelelerinde adaletin sağlanmasında sosyal ağların da bir parçası olduğu büyük veri olarak kavramsallaşmaya başlayan durumun rolüne odaklanmıştır. Twitter örneği üzerinden sosyal ağların, bir kadın cinayeti davası sürecindeki etkisi irdelenmiştir. İntihar olarak kayıtlara geçen olay, sosyal medyada başlayan hak arama mücadeleleri sonucunda -çalışmada sivil/kamu adaletinin, yargı adaletinin tesis edilmesine etkisi olarak kavramsallaştırdığımız durum-, olayın intihar değil de bir cinayet olduğunu açığa çıkarmıştır. Bu çalışma, günümüzün temel çıkmazlarından olan kadın cinayetleri ve kadına yönelik şiddeti bir örnek olayı temel alarak büyük veri üzerinden ele almaktadır. Çalışma büyük veriyi bir olanak olarak incelemesi bağlamında hem özgün hem de önemlidir. 
Çalışma kapsamında konuyla ilgili çok sayıda araştırma sorusu inşa etmek mümkündür. Çünkü sosyal medya bu çalışmada, yeni-yarı kamusal alan olarak kavramsallaştııımış olsa da birçok noktada artık toplumun iletişime geçebildiği bir dayanışma ve hak arayışı uzamına evrilmiştir. Çalışmanın temel amacı ve sınırılıkları göz önünde bulundurularak, çalışmada genel olarak aşağıdaki sorulara yanıt aranmaya çalışılmıştır:

- Büyük veri üzerinden yürüyen sosyal medya tümüyle bir kamusal alan olarak dikkate alınabilir mi?

- Sosyal medyanın, toplumsal konularda ve olaylarda kamuoyunun harekete geçirilmesinde ve böylece de adaletin tesisinde etkili bir mecra olma olasılığı var midır?

- Büyük veri, resmi ve fiili adaleti sağlayan kamu vicdanı ya da kamuoyu için bir uzam olarak kullanılabilir mi?

- Kadına yönelik şiddet ve kadın cinayeti gibi konulardaki hak arayışlarında ve adaletin sağlanmasında sosyal medyanın gücünden söz edilebilir mi?

- Sosyal medya, kamu vicdanına başvurarak adaletin sağlanmasına aracılık edebilir mi?

- Sosyal medya, dezavantajlı grupların sesini duyurmasında ve hak arayışlarında etkili bir ortam mıdır?

\section{Yöntem}

Bu çalışmada, betimsel yönteme başvurularak bir örnek olay seçilmiş ve içerik analiz tekniği kullanılmıştır. Bu bağlamda Şule Çet Davası örnek olayı üzerinden "Adalet,"' Şule Çet Davası ve Bağlantılı Konular," "Bağlantılı Konular" ve "Kamu Desteği Talebi" ana kategorileri altında 18 alt kategori belirlenerek ilgili olay sivil/kamu adaletinin sağlanması bağlamında analiz edilmiştir. 29 Mayıs 2018 tarihinde Ankara'daki bir plazada öldürülen ve plazanın 20. katından atılarak intihar süsü verilen Şule Çet'in dava sürecinde Twitter'da Şule Çet Dayanışma Platformu olarak açılan hesaptan atılan tweetler ve retweetler üzerinden analiz gerçekleştirilmiştir. 


\section{Evren ve Örneklem}

Sosyal medyada konu olan kadın cinayetleri Evreninden seçilen bir kadın cinayeti olarak Adli tutanaklara geçen örnek olay sürecinde Şule Çet'in ağabeyi 13 Temmuz 2018 tarihinde Twitter hesabından "Ben Şenol Çet kardeşim Şule Çet İçin Adalet Arıyorum” diyerek kamuoyunu davaya destek vermeye çağırmıştır. Kadın örgütleri Şule Çet'in öldürüldüğü plazanın önünde ve çeşitli kentlerde eylemler gerçekleştirmişlerdir. Sosyal medya pek çok hak mücadelesinde olduğu gibi Şule Çet için adalet arayışının yürütülmesinde de iletişimi sağlayan zemin işlevi görmüştür. Şule Çet'in ölümünün intihar olarak kayıtlara geçmesi üzerine arkadaşları tarafından Twitter'da Şule Çet İçin Adalet adıyla hesap açılarak olayla ilgili tüm gelişmeler buradan Twitter kullanıcıları ile paylaşılmaya başlanmıştır. Yanı sıra sıklıkla 'trending topic' olan \#ŞuleÇetiçinAdalet, \#ŞuleÇetinSesiOI, \#ŞuleÇet, \#Susma, \#4Aralık'taŞuleÇetDavasındayız hashtagleri ile olayın cinayet olduğu kanaati siber kamusal alanda güçlendirilmiştir. Bu hesaplara konu olan tweet ve retweetler alt evreni oluştururken, sınırlı tarihler arasında ulaşılan 3070 tweet örneklemi oluşturmuştur.

Şule Çet Olayıyla ilgili ilk dava, olaydan yaklaşık bir yıl sonra, yani 6 Şubat 2019 tarihinde açılmıştır. Gerekçeli karar ise 25 Aralık 2019 tarihinde açıklanarak dava sonuçlanmıştır. Bu nedenle çalışmada, ilk olarak, ilgili hesabın 11 aylık sürecini kapsayan 1 Şubat - 31 Aralık 2019 tarihleri arasındaki tweet hareketliliği incelenmiş ve incelemeler grafiklere dönüştürülmüştür. Çalışmanın ikinci aşamasında ise, 2019 yılı içerisinde gerçekleşen 6 davadan 3’nün görüldüğü ve gerekçeli kararın açıklandığı 01 Eylül-31 Aralık 2019 tarihleri arasındaki tweetler ve retweetler (783 tweet ve retweet) nicel içerik analizi yöntemiyle çeşitli kategoriler altında incelenmiştir. Örneklemin 1 Eylül 2019 tarihi itibariyle başlatılma ve 31 Aralık 2019 tarihinde bitirilme nedeni ise gerekçeli karar ile sonuç raporunun yazıldığı ve 2019 yılında görülen 6 davadan 3'ünün yer aldığı tarih aralığı olmasıdır.

Çalışmada Twitter'da @suleicinadalet kullanıcı adıyla aktif olan Şule Çet Dayanışma Platformu'nun, örneklem aralığındaki verilerinin toplanmasında Twitter API (Application Programming Interface) üzerinden $\mathrm{R}$ Studio (R programlama dili için bütünleşik bir geliştirme ortamı) uygulaması kullanılmıştır. Böylece belirtilen tarihler arasında 3070 tweet toplanmıştır. 


\section{İşlem}

Elde edilen bu veriler, Workbench ve Excel programları yardımıyla analiz edilmiştir. Oluşturulan kategorilere ve inceleme biçimlerine ilişkin bilgiler açıklanmıştır. Dava sürecinde \#Şuleçetiçinadalet, \#ŞuleÇetiçinAdalet, \#ŞuleÇetinSesiOI, \#ŞuleÇet, \#Susma, \#4Aralık'taŞuleÇetDavasındayız gibi etiketler üzerinden kadın örgütleri, hukukçular, akademisyenler, siyasi aktörler ve kamuoyunun tanıdığı kişiler tarafından adaletin yerini bulacağına dair inancı güçlendirici ve olayla ilgili kamunun farkındalığını canlı tutan tweetler atılmıştır.

Çalışma kapsamında 1 Eylül 2019 - 31 Aralık 2019 tarihleri arasında Şule Çet Dayanışma Platformu'nda paylaşılan 783 tweet içerik çözümlemesi yöntemiyle analiz edilerek adalet kavramının hangi vurgularla kullanıldığının ortaya konulması amaçlanmıştır. Nicel içerik analizi için örneklem olarak bu tarih aralığının belirlenme nedeni ise, altı duruşmadan son üçüne (4. Duruşma 16 Ekim; 5. Duruşma 20 Kasım; karar duruşması olan 6. Duruşma 4 Aralık) ve gerekçeli kararın açıklanma tarihine (Gerekçeli Karar 25 Aralık) denk gelmiş olmasıdır.

Kodlama cetveli Ek 1'de, tutarlılık oranı hesaplaması ise Ek 2'de sunulmuştur. Ek 2'deki formülde payın, paydadan küçük olması gerektiğinden, iki kodlayıcıdan, kodlaması küçük olan paya yerleştirilmiş ve bu tüm kategorilere uygulanmıştır. Ek 2'de tutarlılık payları 'Kamu Desteği Talebi' kategorisi için 100 tweet üzerinden, yani küçük olan sayı büyük olana bölünerek;'Adalet Kategorisi,'Şule Çet Davası ve Bağlantılı Konular Kategorisi' ile‘Bağlantılı Konular Alt Kategorisi' için ise ilgili kategorilerde yapılan toplam kodlama (çoklu kodlama olmasından dolayı) üzerinden hesaplanmıştır. Hesaplamalar sonucunda Tablo 1'deki oranlara ulaşılmıştır. Tüm kategoriler bağlamında tutarlııı payları \%80,80 ile \%100 arasında değişiklik göstermektedir.

\section{BULGULAR}

\section{Örnek Olay}

Türkiye'de kadın cinayetleri makro ölçekli ve çözüm üretilmeyen/üretilemeyen toplumsal bir sorun olarak karşımızda durmaktadır. Kadın cinayetlerinin durdurulmasına yönelik farklı platformlarda mücadele edilirken sosyal medya da konuyla ilgili bir kamusal dayanışma alanı olarak işlev görmektedir. Şule Çet Davasının bu çalışmada örneklem 
olarak seçilmesinde, 2018 Mayıs ayından itibaren konunun ve dava sürecinin sosyal medya aracılığıyla gündemde tutulması ve intihar olarak üzeri örtülen bir kadın cinayetinde sivil toplumun baskı ve mücadelesiyle adaletin tesis edilmesi etkili olmuştur. Ayrıca konuyla ilgili Türkiye ölçeğinde ilk başarılı örnek olan bu dava, intihar olarak nitelendirilerek kapatılan kadın ölümleriyle ilgili cinayet iddiasıyla yeni davaların açılmasına yol açmıştır ve bu konudaki hak arayışlarının gelecekte de süreceğinin işaretlerini vermiştir. Bu da büyük verinin olumlu gücüne örnek teşkil etmektedir.

Kamuoyunda'Şule Çet Davası' olarak bilinen ve sosyal medya aracılığıyla sürdürülen adalet arayışının sembolü haline gelen olay 29 Mayıs 2018 tarihinde yaşanmıştır. Gazi Üniversitesi öğrencisi Şule Çet, Ankara'daki lüks bir plazanın 20. katından düşerek yaşamını yitirmiştir. Çet'in şüpheli ölümü başlangıçta, olay anında yanında bulunan Çağatay Aksu ve Berk Akand'ın ifadeleri doğrultusunda intihar olarak yansıtılmıştır. Bu süreçte olayın bir numaralı şüphelisi olarak Aksu ve Akand iki kez gözaltına alınıp, her ikisinde de adli kontrol şartıyla serbest bırakılmıştır. Ancak olaydan kısa bir süre sonra Şule Çet'in babası, ağabeyi, arkadaşları, kadın örgütleri ve bazı siyasi aktörler öncülüğünde sosyal medya, ağırlıklı olarak da Twitter üzerinden hak arama mücadelesi başlatılmıştır

Kamu vicdanının harekete geçmesinde Şule Çet'in olay gecesi ev arkadaşına gönderdiği, Çağatay Aksu tarafından zorla alıkonulduğu ve cinsel saldırıya uğradığına dair kısa mesajlar da etkili olmuştur. İstanbul Adli Tıp Kurumunca hazırlanan otopsi raporunda Çet'in öldürülmeden önce tecavüze uğradığı, kanında uyumayı kolaylaştıran uyarıcı madde bulunduğu ve vücudunda boğuşma izleri ile tırnak altında katil zanlısı Çağatay Aksu'ya ait doku kalıntıları ve DNA bulgularına rastlandığı açıklanmıştır. 14 Temmuz 2018 günü Aksu ve Akand, cebir, tehdit veya hile kullanarak kişiyi hürriyetinden yoksun bırakma ve cinsel saldırı suçlarından tutuklanmıştır. Ankara Cumhuriyet Savcısı Alev Ersan Erbuz, Şule Çet'in cesedinden elde edilen bulguları İstanbul Adli Tıp Kurumu'na Eylül ayına dek göndermediği gerekçesiyle görevden alınırken, soruşturma dosyası Ankara Cumhuriyet Savcısı Hüseyin Köse'ye verilmiştir. 3 Aralık 2018 tarihinde Ankara Cumhuriyet Başsavcılığınca hazırlanan iddianamede iki sanık hakkında cinayet, ırza geçme ve hürriyeti tahdit suçundan ağırlaştırılmış müebbet ve 39 yıl hapis cezası istenmiştir. Ayrıca iddianamede Çet'in cinsel saldırıya uğradığı, darp edildiği ve 20. katta bulunan dairenin camından atıldığı belirtilmiştir (Kepenek, \& Öztokat, 2018).

Şule Çet Davasında ilk duruşma 6 Şubat 2019 tarihinde yapılmıştır. 15 Mayıs 2019 tarihinde yapılan ikinci duruşmayı 10 Temmuz 2019, 16 Ekim 2019 ve 20 Kasım 2019 
tarihinde yapılan duruşmalar izlemiştir. Kararın çıktığı duruşma ise 4 Aralık 2019 tarihinde görülmüştür. Dava sürecinde psikiyatri uzmanlarından oluşan heyet tarafından hazırlanan bilirkişi raporunda Çet'in psikolojik durumunun intihara meyilli olduğuna dair bir bulguya rastlanmadığı vurgulanırken, farklı üniversitelerden iki adli tıp profesörünün olay yerinde canlandırma tekniği uygulayarak hazırlamış olduğu 'bilimsel uzman mütalaası' ile olayın intihar değil cinayet olduğu açıklanmıştır.

31. Ağır Ceza Mahkemesinde görülen davanın 4 Aralık 2019 günü yapılan karar duruşmasında, tutuklu sanık Çağatay Aksu'ya ağırlaştırıımış müebbet ve 12 yıl 6 ay, Berk Akand'a ise 18 yıl 9 ay hapis cezası verilmiştir. Bununla birlikte sanıklara iyi hal indirimi uygulanarak Aksu'nun ağırlaştırılmış müebbet cezası müebbet hapis cezasına çevrilmiş̧ir. Bu durum kamuoyunda tepkilere neden olmuş ve konu istinafa taşınmıştır. Davanın müdahillerinden biri olan Aile, Çalışma ve Sosyal Hizmetler Bakanlığı, iyi hal indirimine itiraz yoluna gitmiştir. Bakanlık, kararın, toplum vicdanını yaralayacak nitelikte olduğunu ve cezanın amacına ulaşmasını engelleyeceğini, yaptığı yazılı açıklamayla belirtmiştir.

Şule Çet Davasında gerekçeli karar 25 Aralık 2019 tarihinde açıklanmıştır. Kararda Sanık Çağatay Aksu'nun olay gecesi Şule Çet'e cinsel saldırıda bulunduğu, Çet'in direnmesi üzerine darp ettiği ve boğazını sıktığı ve bu nedenle şuurunu kaybeden maktulü intihar süsü vermek amacıyla 20. kattan aşağı attığı ifade edilmiştir. Kararda sanık Berk Akand'ın da sanık Çağatay Aksu'ya yardım ettiği belirtilmiştir (Uludağ, 2019). Mahkemenin kararı geleneksel ve sosyal medyada adaletin tesisi olarak yorumlanmıştır.

\section{Tweetler Üzerinden Yapılan İçerik Analizleri}

Incelenen tarihler arasında hesaptan atılan toplam 3070 tweet, 840.120 kez retweet yapılırken, fav sayısı 2.593.206 olmuştur. Tweetlerin dili Türkçe ve İngilizcedir. Çalışma açısından, Twitter'da etkileşimin yoğunlaştığı tarihlerin davadaki önemli günler ve yeni gelişmelerle uyumlu olup olmadığı da önem taşımaktadır. Bu amaçla atılan tweetlerin, yapılan retweetlerin ve alınan favların yükseldiği tarihlere bakılmış ve yükselişlerin çoğunlukla duruşma günlerinin bir kaç gün öncesi ve sonrasında olduğu saptanmıştır. Buna göre en yüksek tweet, retweet ve fav (favori) sayısına, karar duruşmasının yapıldığı 4 Aralık 2019 tarihinde ulaşıldığı görülmüştür. Şekil 1'de de yer aldığı üzere söz konusu tarihte hesaptan 68 tweet, 62.587 retweet atılmıştır. Illk duruşma tarihi olan 6 Şubat 2019 tarihinde ise tweet sayısının 120'ye yükseldiği görülmektedir. Bu tarihte retweet 
sayısı ise 36.075 olmuştur. Olaydan 9 ay gibi bir süre sonra görülen ilk duruşmada tweet ve retweet sayısının artışı, sosyal medya aracılığıyla kamunun olaya müdahale ettiği şeklinde yorumlanmıştır. Sonraki duruşmalarda da sıradan günlere kıyasla tweet ve fav sayısının yükseldiği görülmektedir. Yanı sıra 8 Mart Dünya Kadınlar Günü, 25 Kasım Kadına Yönelik Şiddete Karşı Uluslararası Mücadele Günü gibi kadınlarla ilgili önemli günlerde de etkileşimin arttığı dikkat çekmektedir.

Twitter'ın herhangi bir paylaşıma olan ilgiyi gösteren kullanıcı eylemlerinden biri olarak fav sayısı, çalışmamız için önemli bir bulgu olarak değerlendirilmektedir. Şekil 2'de 1 Şubat 2019 - 31 Aralık 2019 tarihleri arasında Şule Çet Dayanışma Platformu'nun yapmış olduğu paylaşımlara yönelik fav sayıları yer almaktadır. Tweet sayılarında olduğu gibi duruşma tarihlerinde fav sayılarının da yükseldiği anlaşılmaktadır. Illk duruşma tarihinde atılan tweetler 186.666 fav almış, bu sayı karar duruşmasının yapıldığı 4 Aralık 2019 'da ise 312.875 'e çıkmıştır. Ayrıca davanın seyrini etkileyecek olumlu gelişmelerin olduğu tarihlerde de etkileşimin arttığı gözlenmektedir. Örneğin 21 Mayıs 2019 tarihinde açıklanan ve Şule Çet'in intihar eğiliminde olmadığı kanaatini taşıyan bilirkişi raporunun ardından etkileşim artmış, hesaptan 32 tweet atılmış, 6374 retweeet ve 37.315 fav yapılmıştır. Gerekçeli kararın açıklandığı 25 Aralık 2019 tarihinde ise 22 tweet atıııken, retweet sayısı 15.368, fav sayısı ise 40.851 olmuştur.

Başlangıçta kayıtlara intihar olarak geçen, ancak bir süre sonra olayın cinayet olduğuna dair kamusal düzeyde de hak arama mücadelesine dönüşen Şule Çet Davasında sosyal medya aracılığıyla verilen mesajlarda adalet kavramının öne çıktığı görülmektedir. \#Şuleçetiçinadalet bu süreçte en fazla kullanılan hashtag olurken, Görsel 1'de sunulan kelime bulutundan da anlaşılacağı üzere bu etikette en fazla tekrarlanan kelimeler'şule, adalet, şule için ve şuleçetiçinadalet' olmuştur.

Öncelikle incelenen tarih aralığında atılan tweetlerin konusunun doğrudan Şule Çet Davası ile ilgili olup olmadığına bakılarak, doğrudan ilgili olanlar 'Şule Çet Davası' kategorisine, ilgili olayla bağlantılı olan konular ise 'Bağlantılı Konular' kategorisine yerleştirilmiştir. Toplam 783 tweet, bu bağlamda 799 kez kodlanmış ve yüzde hesaplaması bu rakam üzerinden alınmıştır. 783 tweetin, \%64,08'i ( $n=512)$ Şule Çet Davası, \%34,29'u ( $n=274)$ Bağlantılı Konular, \%1,63'ü ise ( $n=13)$ ise Diğer kategorisine kodlanmıştır (Şekil 3). Bağlantılı Konular kategorisine kodlanan 274 tweet, çoklu kodlama tekniğiyle 286 kez kodlanmış ve bu kategorideki yüzdeler, 286 rakamı üzerinden alınmıştır. Ayrıca 16 tweet de hem Şule Çet Davası hem de Bağlantılı Konular kategorisine aynı anda 
kodlanmıştır. Bağlantılı konular ise 'Kadın Cinayeti,',Cinsel İstismar' 'Kadına Yönelik Şiddet,', 'Çocuk Cinayeti,' 'Çocuk İstismarı,',Kaybolan Şahıslar,','Erkek Cinayeti' ve 'Diğer' şeklinde alt kategorilere ayrılarak analiz edilmiştir. Ama Diğer kategorisine hiçbir veri kodlanmamıştır.

Gerek Şule Çet Davası gerekse bağlantılı konularda atılan 783 tweette adalet kavramının hangi bağlamda kullanıldığı analiz edilirken, 'Adaletin Tesisi', 'Adaletsizlik Vurgusu,' 'Adalet Umudu', 'Adalet Çağrısı' ve 'Diğer' kategorileri oluşturularak adaletle ilgili hangi durumlara vurgu yapıldığı saptanmaya çalışılmıştır. Tweetler bu kategorilere 911 kez kodlanmış (çoklu kodlama) ve yüzdeler bu rakam üzerinden alınmıştır. Şekil 4'te görüldüğü üzere, toplam 783 tweetin \%67,18'i adalet çağrısı, \%12,95'i adaletsizlik vurgusu, \%12,18'i adalet umudu, \%3,95'i adaletin tesisi ve \%3,73'ü ise diğer konular hakkındadır. Elde edilen veriler, hesaptan atılan tweetlerin ana temasının adalet olduğunu göstermektedir. Zira Şule Çet Dayanışma Platformu'nda yer alan içeriklerde bu davaya yönelik adalet çağrısının yanı sıra kadın cinayetleri, kadına yönelik cinsel istismar ve fiziksel şiddet konularında adalet arayışlarının ağırlık kazandığı görülmüştür. Kadın Cinayetlerini Durduracağız Platformu, Kadın Meclisleri, Kadın Davası gibi eril tahakküm ve erkek şiddetinin karşısında yer alan ve bu çerçevede sivil/kamu vicdanına seslenen kadın platformlarının Twitter'daki paylaşımları Şule Çet Dayanışma Platformu hesabı üzerinden de dolaşıma sokulmaktadır. Bu veriler, Şule Çet olayının, kadına yönelik şiddet ve kadın cinayetlerine dair bir sivil adalet arayışının sembolüne dönüştüğünü göstermektedir.

Doğrudan Şule Çet Davası ile ilgili olan 512 tweet incelendiğinde adalet vurgusunun çeşitli biçimlerde içerikte yer aldığı görülmüştür. Bu tweetlerin \%65,52'sinde adalet çağrısı yapıldığı, \%14,45'inde adaletin yerini bulacağına dair umudun vurgulandığı, $\% 12,15^{\prime}$ inde adaletsizlik vurgusuna yer verildiği, \%5,42'sinde adaletin tesis edildiği yönünde kanaatin oluştuğu saptanmıştır (Şekil 5). Adalet çağrısı yapan tweetler, duruşma öncesi yoğunlaşırken, sanık avukatlarının mahkemeyi etkileme girişimleri, duruşmanın tanıklara kapalı yapılması ihtimalinin gündeme gelmesi, sanıklara son duruşmada iyi hal indirimi verilmesi gibi durumlar tweetlerde adaletsizlik vurgusunu arttıran etkenler olmuştur. Ayrıca davanın seyrini davacı lehine değiştiren bilirkişi raporları, olayın intihar olma ihtimalinin delillerle çürütülmesi, sanık Çağatay Aksu'nun maktule cinsel saldırıda bulunduğu kanaatinin güçlenmesi gibi gelişmeler tweetlerde adalet umuduna dair mesajları arttırmıştır. Dava sürecinde sona yaklaşıııken 'adalet yakındır'mesajının dolaşıma girdiği ve kamunun, adaletin sağlanacağına dair inancının 
güçlendirilmeye çalışıldığı görülmektedir. Adalet tesisi vurgusu ise 4 Aralık 2019'da yapılan karar duruşması ve 25 Aralık 2019'da gerekçeli kararın açıklanmasına bağlı olarak bu tarihlerde öne çıkmıştır.

Çalışma kapsamında, hesaptan atılan tweetlerde somut biçimde kamu desteği talebinin olup olmadığına da bakılmıştır. İncelenen Twitter hesabında, yukarıda da vurgulandığı gibi, Şule Çet ve erkek şiddetine maruz kalan başka kadınlarla ilgili adalet arayışında kamuya, destek ve dayanışma çağrısı yapılımıştır. Özellikle duruşma öncesi günlerde duruşma yeri, tarihi ve saati verilerek, takipçilerin katılımı ve desteği istenmektedir. Nitekim tweetlerin \%39,85'inde ( $n=312)$ 'Kamu Desteği Talebi' bulunmaktadır. Bu kapsamdaki tweetlerin \%67,95'inde ( $n=212)$ Şule Çet Davası için kamu desteği talep edilirken, \%32,05'inde ( $n=111$ )'Bağlantılı Konular' için kamu desteği talebinde bulunulmuştur.

Duruşmalara katılımın yüksek olmasında kamu desteği talep eden paylaşımların etkili olduğu düşünülmektedir. Sanıklar ve sanık avukatlarının sözleri de bu kanıyı güçlendirmektedir. Şöyle ki davanın karar duruşmasında sanık avukatları ve sanıklar sosyal medyadan sürdürülen hak mücadelesine yönelik suçlayııı ifadeler kullanmışlardır. Sanık avukatı, \#ŞuleÇetiç̧inAdalet etiketi üzerinden binlerce tweet atıldığını söyleyerek duruşma salonunun sosyal medyada yapılan çağrılar nedeniyle kalabalık olduğundan şikâyet etmiş ve bu baskının mahkemenin seyrini etkileyeceğinden duyduğu kaygıyı dile getirmiştir. Sanık Çağatay Aksu'nun da, mahkemede "Biz sosyal medya yüzünden tutuklandık. Bir gecede 11 milyon tweet atıldı" şeklindeki sözleri, Twitter üzerinden oluşan kamuoyunun azımsanmayacak ölçüde olduğunu düşündürtmektedir.

4 Aralık 2019 tarihinde yapılan 6. Duruşmada çıkan karar da sosyal medyada yürütülen 'Şule Çet İçin Adalet'kampanyasının başarısı olarak değerlendirilmiştir. Sosyal medyada yapılan yorumlar ve çevrimiçi haber sitelerinde yer verilen içerikler, Şule Çet Davasında başta Twitter olmak üzere sosyal medya dolayımıyla oluşmaya başlayan yeni kamusallığın gücü ve etkisine vurgu niteliğindedir. Örneğin Evrensel gazetesi 5 Aralık 2019 tarihli nüshasında manşetten verdiği habere 'Cezasızlığı Mücadele Önledi' başlığını atmıştır. Benzer şekilde memurlar.net'in (21 Kasım 2019) konuyla ilgili haberinde'Yargının çarkını yine toplum çevirdi' başlığı kullanıımıştır ("Yargının çarkını...," 2019).

Şule Çet Dayanışma Platformu adlı Twitter hesabında yer alan sabitlenmiş tweette, "1,5 yıldır verdiğimiz mücadele ile Şule'nin huzurla uyumasını başardık. Bu başarı 
hepimizin başarıııdır. Şule için en ufak katkısı olan herkese teşekkür ederiz. Hepinizin güzel yüreklerinden, güzel kalplerinden öperiz" denilerek adaletin tesisi yönünde destek veren Twitter kullanıcılarına teşekkür edilmiştir. Başarı, sivil/kamu adaleti olarak nitelendirilmiştir.

Şule Çet olayı ile doğrudan ilgili olmayıp bağlantılı olarak analiz edilen bu konular arasında Şekil 6'da da görüleceği üzere Kadın Cinayetleri kategorisi öne çıkmaktadır. Son yıllarda Türkiye'de giderek artan ve büyük bir toplumsal sorun haline gelen kadın cinayetlerinin durdurulması, şiddet gören ya da ölüm tehdidi alan kadınların güvenliklerinin sağlanması, öldürülen kadınların faillerine gereken cezanın verilmesi, sanıklara verilen iyi hal ve haksız tahrik indirimlerinin önlenmesi gibi konularda paylaşımların yapıldığı hesapta, kadın cinayeti davalarına kamunun desteği istenmekte ve kamusal katılımın sağlanması çağrısı yapılmaktadır. Analiz bulgularına göre hesaptan, bağlantılı konularla ilgili atılan tweetlerin \%70,28'inde kadın cinayetleri, \%13,29'unda kadına yönelik şiddet, \%5,59'unda cinsel istismar, \%4,20'sinde çocuk cinayeti, \%3,50'sinde erkek cinayeti, \%2,80'inde çocuk istismarı, \%0,35'inde kaybolan şahıslar ve \%0,72'sini ise erkek cinayeti konuları yer almaktadır. Bu kategoride 'Diğer' alt kategorisi de oluşturulmuştur. Ama bu kategoriye herhangi bir kodlama yapılmadığı için, ilgili kategori grafiğe konulmamıştır.

\section{TARTIŞMA VE SONUÇ}

Günümüzde sosyal medya kimi kez toplumsal konular hakkında enformasyonun aktarıldığı, kamu vicdanının harekete geçirildiği ve hak mücadelelerinin yürütüldüğü bir zemin olarak işlev görmektedir (Babacan, 2015; Dilitemiz Mol, 2016; Tekvar, 2017). Bu çalışma kapsamında ele alınan Şule Çet Davasında da sosyal medyanın, yani yeni yarı kamusal alanın Şule Çet'in ölümüyle başlayan süreçte farkındalık yaratan, kamunun konuya yönelimi ve desteğini sağlayan bir mecra olarak adaletin tesisinde rol oynadığı düşünülmektedir. Başlangıçta intihar olarak değerlendirilen ancak yargı sürecinde cinayet olduğuna hükmedilen olayda, sürdürülen 1,5 yıllık hak arayışının önemli bir ayağını Twitter oluşturmaktadır. Çalışma kapsamında elde edilen veriler de bu düşünceyi desteklemektedir. . Olayın cinayet olduğuna resmi kurumlar karar vermiş ve cezayı da yine resmi kurum olan yargı vermiştir. Ama sürecin bu şekilde işlemesinde ve olayın her anının takip edilmesinde Twitter büyük bir olanak sağlamış ve sivil/kamu vicdanını süreç boyunca özgür bir biçimde görünür kılarak adaletin sağlanmasına katkı yapmıştır, hatta adaleti sağlamıştır da denilebilir. 
Şule Çet Dayanışma Platformu'nda, kadın ve çocuk cinayetleri, cinsel istismar, intihar ve şiddet gibi konularda adalet arayışlarının sürdürüldüğü, kamu farkındalığının arttırımaya çalışıldığı, sivil/kamu adaletinin göreve çağııldığı ve böylece hak arama mücadelesinin eksen olarak genişletildiği görülmüştür. Aynı örneklem ya da konuyla ilgili olmasa da sosyal medyanın bu doğrultudaki gücüne vurgu yapan çok sayıda çalışma mevcuttur (Timisi, 2003; Yarar, 2016; Yegen, 2013; Sarıŏlu, 2020) Örneğin Yarar (2016) dijital aktivizm kavramını tartıştığı çalışmasında günümüzde dijital iletişim teknolojilerinde yaşanan gelişmelerin toplumsal hareketleri yeni bir boyuta taşıdığını söylemektedir. Timisi'nin (2003) internetin; kolay erişim, enformasyona erişimde hız ve kolaylık, otoritelerden bağımsız örgütlenme olanağı, siyasal katılımı arttıran ve sivil toplumu genişleten bir olanak olduğu şeklindeki tespitlerini hatırlatan Yarar (2016, p. 215), toplumsal hareketlerin bugün gelinen noktada aynen birbirine bağlı bilgisayarlar gibi ağ örgütlenmesi görünümü sergilediğini söylemektedir. Yarar (2016, p. 222) yeni dijital aktivist hareketlerin forumlar ve sosyal medya aracılığıyla sürerken siber uzamda oluşturulan alternatif kamusal alanın sokağa, kente taşınma kapasitesine dikkat çekmektedir. Bu çalışmada elde edilen bulgular da siber uzamda başlayan adalet arayışının -özellikle duruşma günleri öncesinde- kamu desteği talebine dönüştüğünü ve kamunun davaları izlemeye ve destek vermeye çağrıldığını göstermektedir.

Sosyal medyanın adalet arayışına olan katkısını inceleyen bir çalışma da Sarıoğlu (2020) tarafından yapılmıştır. Sarıoğlu (2020), kadına ve çocuğa yönelik şiddet üzerinden irdelediği çalışmasında, siber uzamdaki sivil dayanışma ve mücadelenin davaların seyrini failin aleyhine değiştirdiğini vurgulamaktadır. Sarıoğlu (2020), kadın cinayetleri, kadına yönelik fiziksel şiddet, kadına yönelik cinsel istismar, çocuğa yönelik fiziksel şiddet, çocuğa yönelik cinsel istismar kapsamındaki 14 örnek olaya dair önce ana akım medyada yer alan haberleri ardından ise Twitter'da paylaşılan içerikleri incelediği çalışmasında, örnek olayların dava seyrinin sosyal medyadaki etkileşimler sonucu mağdur lehine değiştiğini ortaya koymuştur. Sosyal medyayı adaletin sağlanmasında itici güç olarak nitelendiren Sarıoğlu (2020), ele aldığı örnek olaylarda başlangıçta faillerin gözaltı sürecinin ardından serbest bırakıldığını, ancak ana akım medyada konunun haber olarak yer almasıyla başlayan kamu farkındalığının, sosyal medyada güçlenerek arttığını ve adaletin tesisi yönünde sürdürülen mücadele ile dava seyrinin değiştiğini vurgulamaktadır.

Bu çalışmanın bulguları da öldürülen bir kadının ardından sürdürülen hak arayışı için açılan Şule Çet Dayanışma Platformu hesabında kadın cinayetleri ve kadına yönelik 
şiddet konusundaki paylaşımların öne çıktığını göstermektedir. Şule Çet Davasında adaletin gerçekleşmiş olması, üzeri örtülmüş başka bir benzer davada da sosyal medya üzerinden hak arama mücadelesini gündeme getirmiştir. 2018 yıı Şubat ayında çalıştığı işyerinin 3. katından düşerek yaşamını yitiren, polisin olay yeri inceleme tutanağında şüpheli ölüm olarak kayda geçmesine rağmen takipsizlik kararı verilen Aysun Yıldırım davası yeniden yargıya taşınmıştır. Dosyanın tekrar açılması üzerine yapılan DNA incelemesinde Aysun Yıldııım'ın tırnaklarının arasında erkek arkadaşı O.T'ye ait doku bulunmuş ve 14 Aralık 2019'da O.T. hakkında yakalama kararı çıkarıımıştır. Ayrıca Çet davasında olduğu gibi Aysun Yıldııım davasının da intihar değil cinayet olduğuna dair Twitter'da \#AysunYıldırımiçinAdalet hashtagi ile adalet arayışı başlatılmışır. Şule Çet Dayanışma Platformu'ndan atılan tweetlerde Şule Çet için olduğu gibi Aysun Yıldırım için de gerçeklerin açığa çıkarılacağına ilişkin mesajlar dolaşıma girmekte ve kamu vicdanına seslenen çağrılar yapılmaktadır. Aysun Yıldırım davası örneğinde olduğu gibi Şule Çet Davasının intihar olarak kapatılan şüpheli kadın ölümlerini yeniden gündeme getirerek sosyal medya üzerinden kamu vicdanını harekete geçireceği ve sivil/kamu adaletinin tecelli etmesine kapı aralayacağı düşünülmektedir.

Web 2.0 teknolojisinin sunduğu bir olanak olarak görülebilecek olan sosyal ağlar, bireylerarası ilişkilerin sürdürülmesine aracılık ettiği kadar, toplumsal konularda sağlamış olduğu kamusal ortam nedeniyle de önemli bir yere sahiptir. Özellikle dezavantajlı kesimlere yönelik ayrımcılık ve şiddet içeren olaylarda sosyal ağlar, kamu vicdanının harekete geçirilmesinde, hak ihlaline uğrayan kişi ve gruplara destek veren bir dayanışma ağının oluşmasında, siber ortamda yürütülen mücadelenin çevrimdışı eylem ve pratiklerle de sürdürülmesinde, kısacası sivil toplumun tesisinde demokratik bir zemin olarak değerlendirilebilir. İktidardan görece bağımsız olan sosyal ağlar katıımı/katılımcı kültürü güçlendirdikleri gibi ana akım medyanın görmezden geldiği dezavantajı gruplara da alan açmakta, çeşitli ihlallere uğrayan kadınların, çocukların, yaşılıların, engelli bireylerin, göçmenlerin, mültecilerin ve sığınmacıların seslerini duyurmalarına olanak tanımaktadır (YMK4, 2019).

Çalışmanın girişinde de ifade edildiği üzere dijital sosyal ağları mutlak bir kamusal alan olarak değerlendirmek doğru bir yaklaşım olmayacaktır. Nitekim sermaye ve mülkiyet yapıları göz önüne alındığında geleneksel medya ile benzer biçimde sosyal ağların ardında da küresel sermaye kuruluşlarının olduğu aşikardır. Ayrıca sosyal ağlar, Habermas'ın kamusal alan düşüncesi üzerinden değerlendirildiğinde, en baştan aleniyet ilkesinin uzağında kalmakta, sanal ve anonim kimlik kullanımı bu alanda faaliyet gösteren 
aktörlerin sahiciliğini gölgelemektedir. Bu nedenlerle çalışmada, sosyal ağların, güçlü bir kamusal alan olarak görülmelerini engelleyen özellikleri dikkate alınarak yarı kamusal alan kavramının kullanılması tercih edilmiştir.

Yakın geçmişte sosyal ağların toplumsal dayanışma ve hak arama mücadelelerinin örgütlenmesine olanak tanıyan yönünü gösteren pek çok örnek bulunmaktadır. 2009 yılında İran'daki seçimlere hile karıştığı gerekçesiyle başlayan ve 'Twitter devrimi' olarak adlandırılan toplumsal hareketten Arap Baharı ve Gezi Olaylarına dek sosyal ağların kamuoyu oluşturma işlevi tartışılmaktadır. Ayrıca toplumsal hareketler bağlamında sosyal medya aracılığıyla oluşan kamusallık üzerine yapılmış çok sayıda akademik çalışma bulunmaktadır. Domino etkisi diye tanımlanan Arap uyanışı, bir toplumsal hareket olarak internet ve sosyal medya dolayımıyla giderek genişleyen ve güçlenen bir konu olarak çokça çalışıımıştır. Söz konusu çalışmalar, 2010 yılında Tunus'tan başlayıp Mısır, Bahreyn, Cezayir, Suriye, Ürdün, Yemen ve Libya gibi ülkelerde yaşanan halk ayaklanmaları, protestolar ve mitinglerin örgütlenmesinde kamuoyunun oluşumu ve halkın sokağa çıkmasıyla internet ve Facebook, Twitter gibi sosyal ağların etkili olduğunu vurgulamaktadır (Babacan et al., 2011; Kırık, 2012; Akbıyık, \& Öztürk, 2012; Korkmaz, 2012; Topal Demiroğlu, 2014; Babacan, 2014; Breuer et al., 2015; Hülür, \& Akçay Bekiroğlu, 2016, Sine, 2017).

Büyük veri, iktisadi ve siyasal olarak tarafsız değildir. Üretildiği ve dağıtıldığı bölgenin kültürünü, ideolojisini içinde barındırır. Fakat böyle bir özellik göstermeyen bir yapıya ya da oluşuma dünya üzerinde rastlamak olanaklı değildir. Öyleyse elimizdeki bu tür teknik yapıların sunduğu olanaklara ya da oluşturduğu engellere odaklanmak gerekir. Kuramsal bölümde de sıklıkla değindiğimiz gibi büyük veri ve bunun bir parçası olan sosyal ağlar, topluma, ülkeye, bölgeye göre avantaj sağlayabileceği gibi dezavantajlar da sunabilir. Bu nedenle, elimizdeki araçları kullanma şeklimiz önemlidir.

Büyük veri temelli sosyal ağlar, inşa etmeye başladıkları yeni ve farklı bir kamusal alanda, mevcut kamusal alanın olanaklarını genişletmeye başlamıştı. Kamusal alanı paylaşan kamusal topluluğun iletişime ve etkileşime girmesini zaman açısından hızlandırmış ve mekân açısından ise görece bağımsızlaştırmıştır, hatta mekânız mekân olarak kamusal topluluğun sınırlarını ulus ötesine taşıyacak kadar genişletmiştir. Sosyal ağların bu temel özellikleri, toplumların veya dünyanın dezavantajı gruplarına, kendilerini görünür kılma ya da haklarını aramada önemli fırsatlar sunmaktadır. Sosyal ağların kamusal alan olarak kullanılması ve devlet ya da siyasal erk üzerinde daha fazla baskı 
kurarak sosyal adaletin sağlanmasına ya da kamu vicdanının işleyiş̧ine neden olabilmesi için daha eşitlikçi ve demokratik teknoloji politikalarına gereksinim vardır.

Büyük veriyi üreten, yaygınlaştııılan ve barındıran bir dijital ortam olarak Twitter aracılığıyla sürdürülen bir adalet arayışının konu edildiği bu çalışma göstermiştir ki, kadın cinayetleri ya da kadına yönelik şiddet uygulamaları sosyal ağlar üzerinden daha görünür hale gelmektedir. Bu ağlar, kadınlara hem toplumsal yaşamda hem de yasal süreçlerde lehte durumlar sunabilmektedir. Sosyal ağlar, güç merkezleri üzerinde uyguladıkları kamu vicdanı baskısıyla, sorunların çözülebilmesini ve adaletin tesis edilebilmesini sağlayabilmektedirler. Fakat şu noktanın belirtilmesi önemlidir: Sosyal ağ üzerinden yürütülen mücadeleler, insan hakları lehinde sonuçlanıyorsa bu bir olanaktır. Çünkü sosyal medya üzerinden sadece hak mücadeleleri değil, siyasal kampanyalar gibi kamuyu yönlendirici ve manipüle edici süreçler de yürütülebilmektedir. Bu tür sosyal medya süreçleri üzerine düşünmek ve tartışmak gerekmektedir. Özellikle bu yeni kamunun, ne türden bir kamu olduğu ve şirketlerin elinde olma durumu irdelenmelidir. Nihayetinde bu yeni-yarı kamusal alanın hareketini sağlayan ve bu alandaki verileri toplayan kamusal organlar değil, şirketlerin kendisidir. Bu nedenle yeni-yarı kamu hem Fuchs'un (2014) hem de Jenkins'in yaklaşımları bağlamında sorunlar ve olanaklar bağlamında ele alınmalıdır. Bu çalışma, kısmen Jenkins'in (2016) düşünceleri doğrultusunda olaya yaklaşmış ve sosyal ağların olanaklar yaratabildiğini, başka bir anlatımla hak arama mücadelelerine ortam olarak aracılık edebildiğini göstermiştir. Şöyle ki, büyük veri, istenildiğinde, gözetim ve denetimin dışında da işlevsel olabilecek bir potansiyel taşımaktadır.

Son olarak büyük verinin sağladığı olanakları daha demokratik ve katılımcı düzeye taşımak için çalışmaların yapılması ya da yeni siyasi ve iktisadi politikaların geliştirilmesi gerektiğini belirtmekte yarar vardır. Sosyal ağlar, tam olmasa da bir kamusal alan inşa etmişlerdir. Bu alanın tümüyle kamusal alan özelliği gösterebilmesi için, devletlerin, bu alandaki etkinliklerini ve denetimlerini azaltmak ama aynı zamanda yine bu ortamların güvenliğini ve kullanılabilirliğini/erişilebilirliğini kamusal topluluk lehinde geliştirmesi ve garanti altına alması gerekmektedir. Sosyal ağların tam anlamılla kamusal alan niteliği gösterebilmesi için herkesin erişimine açılması, herkesin gerçek kimlikleriyle kendilerini ilgili ortamda var etmesi ve yine bu teknolojiye dayalı kamusal alanın kullanımına ilişkin teknik bilginin herkese verilmesi gerekmektedir. Son olarak, hak mücadelelerinde bu yarı kamusal alanın gücü dikkate alınmalı, kamuoyu gerektiren durumlarda yarı kamusal alan yoluyla kendisini görünür kılmaya çalışan sivil/kamu 
adaleti/vicdanı görmezden gelinmemelidir. Nitekim çalışmanın konusunu oluşturan Şule Çet Davası'nda bir sosyal ağ sitesi olan Twitter üzerinden sağlanan dayanışma ve hak arama mücadelesinin ne denli önemli olduğu anlaşılmaktadır. Böyle bir dayanışma ağı olmaksızın belki de üzeri kapatılacak bir davada adaletin sağlanması için zemin hazırlayan çevrimiçi ortam, konuya destek veren Twitter kullanıcılarının adalet arayışını, bizzat davalara katılım göstererek, adliye önünde sivil toplum kuruluşları ve özellikle de kadın örgütlerinin öncülüğünde protestolar yaparak kamusal alana da taşımasını sağlamıştır. Denilebilir ki, sosyal medya sivil adalet arayışını dolayımlayan bir zemin olmasının yanı sıra toplumsal sorunların kamusal alana da taşınarak mücadele verilmesine katkı sağlamaktadır.

Hakem Değerlendirmesi: Dış bağımsız.

Çıkar Çatışması: Yazarlar çıkar çatışması bildirmemiştir.

Finansal Destek: Yazarlar bu çalışma için finansal destek almadığını beyan etmiştir.

Peer-review: Externally peer-reviewed.

Conflict of Interest: The authors has no conflict of interest to declare.

Grant Support: The authors declared that this study has received no financial support.

\section{KAYNAKLAR}

Adaklı, G. (2006). Türkiye'de Medya Endüstrisi: Neoliberalizm Çağında Mülkiyet ve Kontrol İlişkileri. Ankara, Turkey: Ütopya Yayınları.

Adaklı, G. (2010). Neoliberalizm ve medya: Dünya'da ve Türkiye'de medya endüstrisinin dönüşümü. Mülkiye Dergisi, 34(269), 67-84.

Akbıyık, N., \& Öztürk, M. (2012). Sivil toplum ve sosyal medya perspektifinde "Arap baharı" ve “Wall Street'i işgal et" eylemleri. Turgut Özal Uluslararası Ekonomi ve Siyaset Kongresi Il Bildiri Kitapçı̆ı (pp. 19-20).

Al-Khouri, A. M. (2012). Data ownership: Who owns'my data'? International Journal of Management \& Information Technology, 2(1), 1-8.

Anderson, J. W. (2003). New media, new publics: Reconfiguring the public sphere of Islam. Social Research: An International Quarterly, 70(3), 887-906.

Arendt, H. (2018). Kamu Vicdanına Çağrı: Sivil İtaatsizlik (Y. Coşar, Trans.). İstanbul, Turkey: Ayrıntı Yayınları. Atabek, Ü. (2013). Yeni medya ve yeni iletişim düzeni. Mülkiye Dergisi, 37(3), 175-182.

Babacan, M. E. (2014). Sosyal medya sonrası yeni toplumsal hareketler. Birey ve Toplum Sosyal Bilimler Dergisi, 4(1), 135-160.

Babacan, M. E. (2015). Yeni medya bağlamında toplumsal hareketler ve yeni insanın karakter analizi. Folklor/ Edebiyat, 21(83), 295-307. 
Babacan, M., Haşlak, İ., \& Hira, İ. (2011). Sosyal medya ve Arap Baharı. Akademik Incelemeler Dergisi (AID), 6(2), 63-92. Baran, K. S., Fietkiewicz, K. J., \& Stock, W. G. (2015). Monopolies on social network services (SNS) markets and competition law. In F. Pehar, C. Schlögl, C. Wolff (Eds.), Re:inventing Information Science in the Networked Society. Proceedings of the 14th International Symposium on Information Science (ISI 2015), Zadar, Croatia, 19th-21st May 2015 (pp. 424-436). Glückstadt: Verlag Werner Hülsbusch.

Başlar, G. (2013). Yeni medyanın gelişimi ve dijitalleşen kapitalizm. Akademik Bilişim, 823-831.

Bek, M. G. (2010). Karşılaştırmalı perspektiften Türkiye'de medya sistemi. Mülkiye Dergisi, 34(269), 101-125.

Binark, M. B., \& Karataş, Ş. (2016). Yeni medyada yaratıcı kültür: Troller ve ürünleri ‘Caps'ler. TRT Akademi, 1(2), 426-448.

Breuer, A., Landman, T., \& Farquhar, D. (2015). Social media and protest mobilization: Evidence from the Tunisian revolution. Democratization, 22(4), 764-792.

Bulut, Ç. K. (2015). NWICO'dan WSIS'e: Uluslararası iletişimde dönüşüm ve mücadele. Illetişim Kuram ve Araştırma Dergisi, 41.

Carveth, R. (1998). The economics of online media. In A. Alexander, J. E. Owers, R. Carveth, C. A. Hollifield, \& A. N. Greco (Eds.), Media Economics (pp. 265-282). UK: Routledge.

Coşar, Y. (2018). Önsöz: Sivil İtaatsizlik. In Y. Coşar (Ed.), Kamu Vicdanına Çağrı: Sivil İtaatsizlik (pp. 9-28). İstanbul, Turkey: Ayrıntı Yayınları.

Cottle, S. (2011). Media and the Arab uprisings of 2011. Journalism, 12(5), 647-659. https://doi. org/10.1177/1464884911410017

Çalışkan, O. (2014). Kamusal alan bağlamında ağ toplumu ve yeni kamusal alan arayışı. Maltepe Üniversitesi İletişim Fakültesi Dergisi, 1(1), 41-62.

Çildan, C., Ertemiz, M., Küçük, E., Tumuçin, H. K., \& Albayrak, D. (2012). Sosyal medyanın politik katılım ve hareketlerdeki rolü. Akademik Bilişim, 3.

boyd, d., \& Crawford, K. (2012) Critical questions for big data, information / provocations for a cultural, technological, and scholarly phenomenon. Communication \& Society, 15(5), 662-679. https://doi. org/10.1080/1369118X.2012.678878.

Mol, D. (2016). LGBTi hareketinin hak ve temsil mücadelesi ve siyasal iletişim faaliyetleri (Doctoral dissertation, Ankara University, Institute of Social Sciences).

Djankov, S., McLiesh, C., Nenova, T., \& Shleifer, A. (2003). Who owns the media? The Journal of Law and Economics, $46(2), 341-382$.

Downey, J., \& Fenton, N. (2003). New media, counter publicity and the public sphere. New Media \& Society, 5(2), 185-202.

Dursun, O. (2012). Türk medyasının sermaye yapısı ve siyasal iktidarla ilişkisi üzerine bir inceleme. Hitit Üniversitesi Sosyal Bilimler Enstitüsü Dergisi, 5(1), 1-22.

English, C. A. (2013). The public sphere and online social media: Exploring the use of online social media as discursive spaces in an Irish context. https://doi.org/10.14705/rpnet.2013.000086 
Filibeli, T. E. (2016). Gezi parkı protestoları ve haber dili: Barış gazeteciliği perspektifiyle haber analizleri. Galatasaray Üniversitesi Illeti-ş-im Dergisi, 25, 39-74.

Fuchs, C. (2014). Social media and the public sphere. TripleC: Communication, Capitalism \& Critique, 12(1), 57-101. https://doi.org/10.31269/triplec.v12i1.552

Fuchs, C. (2018). Sosyal Medya: Eleştirel Bir Giriş (D. Saraçoğlu, \& I. Kalaycı, Trans.). İstanbul, Turkey: Nota Bene.

Gerhards, J., \& Schäfer, M. S. (2010). Is the internet a better public sphere? Comparing old and new media in the USA and Germany. New Media \& Society, 12(1), 143-160.

Ghannam, J. (2011). Social Media in the Arab World: Leading up to the Uprisings of 2011. Washington DC, USA: Center for International Media Assistance.

Guo, L., \& Vargo, C. (2015). The power of message networks: A big-data analysis of the network agenda setting model and issue ownership. Mass Communication and Society, 18(5), 557-576.

Habermas, J. (1974). The public sphere: An encyclopedia article. New German Critique, 3, 49-55.

Habermas, J. (2001). Iletişimsel Eylem Kuramı (M. Tüzel, Trans.). İstanbul, Turkey: Kabalcı.

Habermas, J. (2018). Sivil İtaatsizlik: Demokratik Hukuk Devletinin Denektaşı / Almanya'da Otoriter Legalizm Karşıtığı. In Y. Coşar (Ed.), Kamu Vicdanına Çağrı: Sivil İtaatsizlik (pp. 122-143). İstanbul, Turkey: Ayrıntı Yayınları. Habermas. J. (2009). Kamusallığın Yapısal Dönüşümü (T. Bora, Trans.). İstanbul, Turkey: Illetişim Yayınları.

Hoeren, T. (2014). Big data and the ownership in data: Recent developments in Europe. European Intellectual Property Review, 36(12), 751-754.

Hurlburt, G. F. (2012). Web 2.0 social media: A commercialization conundrum. IT Professional, 14(6), 6-8.

Hülür, A. B., \& Akçay Bekiroğlu, H. (2016). Ortadoğu'da demokratikleşme sürecinde yeni medyanın yeri. II. Ortadoğu Sempozyumu, 4-7 Mayıs 2016, Kırıkkale, Türkiye.

Jenkins, H. (2016). Cesur Yeni Medya Teknolojiler ve Hayran Kültürü (N. Yeğengil, Trans.). İstanbul, Turkey: Illetişim Yayınları.

Kadıoğlu, Z. K. (2018). Türkiye'de medya sahipliği ekseninde mülkiyet yapılarındaki değişimin kronolojik analizi (1950-2010). Insan \& Insan, 5(16), 100-120.

Kahn, R., \& Kellner, D. (2004). New media and internet activism: From the 'Battle of Seattle'to blogging. New Media \& Society, 6(1), 87-95.

Karagöz, K. (2013). Yeni medya çağında dönüşen toplumsal hareketler ve dijital aktivizm hareketleri. Illetişim ve Diplomasi, 1(1), 131-156.

Kepenek, E., \& Öztokat, E. (2018, December 7). "Şule Çet Cinayeti Kronolojisi." BiA Haber Merkezi. Retrieved from https://m.bianet.org/bianet/toplumsal-cinsiyet/203299-sule-cet-cinayeti-kronolojisi

Khondker, H. H. (2011). Role of the new media in the Arab Spring. Globalizations, 8(5), 675-679.

Kırık, A. M. (2012). Arap Baharı Bağlamında Sosyal Medya-Birey Etkileşimi ve Toplumsal Dönüşüm. 21. Yüzyılda Eğitim ve Toplum Eğitim Bilimleri ve Sosyal Araştırmalar Dergisi, 1(3), 87-98.

Korkmaz, A. (2012). Arap Baharı sürecinde internet ve sosyal medyanın rolü. In International Symposium on Language and Communication: Research Trends and Challenges (ISLC) (pp. 2147-2153). 
Kuyucu, M. (2013). Türkiye'de çapraz medya sahipliği: Medya ekonomisine olumsuz etkileri ve bu etkilerin önlenmesine yönelik öneriler. Selçuk Üniversitesi Illetişim Fakültesi Akademik Dergisi, 8(1), 144-163.

Kuyucu, M. (2014). Medya ekonomisi ve başrol oyuncuları: Bugünün ve yarının medya aktörlerinin gözünde reklamcılar ve tüketiciler. The Turkish Online Journal of Design, Art and Communication TOJDAC, 4(1).

Lawson-Borders, G. (2003). Integrating new media and old media: Seven observations of convergence as a strategy for best practices in media organizations. International Journal on Media Management, 5(2), 91-99.

Loader, B. D. (2008). Social movements and new media. Sociology Compass, 2(6), 1920-1933.

Narin, B., Ayaz, B., Fırat, F., \& Fırat, D. (2017). Büyük veri ve gazetecilik ilişkisi bağlamında veri gazeteciliği. AJIT-e: Online Academic Journal of Information Technology, 8(30), 215-235. https://doi.org/10.5824/1309-1581.2017.5.010.x

Noam, E. M. (2016). Who Owns the World's Media?: Media Concentration and Ownership Around the World. UK: Oxford University Press.

Okerson, A. (1996). Who owns digital works? Scientific American, 275(1), 80-84.

Özsoy, A. (2014). Alternatif Medya, Gezi Parkı Eylemleri ve Çapul TV Örneği. Mersin Üniversitesi Akademik Bilişim Conference, Mersin, Turkey.

Öztürk, F. (2019). Şule Çet davası sonuçlandı: Çağatay Aksu ve Berk Akand cinayet ve cinsel saldırıdan 'iyi hâl indirimli' ceza aldı. BBC Türkçe. Retrieved from https://www.bbc.com/turkce/haberler-turkiye-50660568

Papacharissi, Z. (2002). The virtual sphere: The internet as a public sphere. New Media \& Society, 4(1), 9-27.

Pickard, V. (2015). Media ownership. The International Encyclopedia of Political Communication, 1(4). https://doi. org/10.1002/9781118541555.wbiepc206

Rawls, J. (2018). Sivil itaatsizliğin tanımı ve haklılığı. In Y. Coşar (Ed.), Kamu Vicdanına Çağrı: Sivil Itaatsizlik (pp. 5578). İstanbul, Turkey: Ayrıntı Yayınları.

Sallan Gül, S., Sezer, M., \& Kahya Nizam, Ö. (2015). Eylemcilerin gözünden bir sosyal hareket ve kent hakkı talebi olarak Taksim Gezi Parkı eylemleri. Süleyman Demirel Üniversitesi Sosyal Bilimler Enstitüsü Dergisi, 22, 1-28.

Sandoval, M., \& Fuchs, C. (2015, August 14). Alternatif medyanın eleştirel bir teorisine doğru (D. Sayıntı, Trans.). Ayrıntı Dergi.

Sarıoğlu, E. B. (2020). Sosyal medyada adalet kavramı: Kadına ve çocuğa yönelik şiddetin sosyal medyadaki yansımaları. Karadeniz Uluslararası Bilimsel Dergi, 45, 291-317.

Sine, R. (2017). Alternatif Medya ve Haber Toplumsal Hareketlerde Habercilik Pratikleri. Konya, Turkey: Litera Türk Yayınevi.

Şule Çet davasında sanıklardan skandal savunma (2019, February 2). BirGün Gazetesi. Retrieved from https:// www.birgun.net/haber/sule-cet-davasinda-saniklardan-skandal-savunma-246103

Tekvar, S. O. (2017). Türkiye'de feminist alternatif medyanın işlevselliği: Bir alternatif medya örneği “Kadınların Postası" projesinin incelenmesi. Itobiad: Journal of the Human \& Social Science Researches, 6(1).

Timisi, N. (2003). Yeni Iletişim Teknolojileri ve Demokrasi. Ankara, Turkey: Dost Kitabevi.

Uludağ, A. (2019, December 25). Şule Çet davasında gerekçeli karar açıklandı. Cumhuriyet Gazetesi. Retrieved from http://www.cumhuriyet.com.tr/haber/turkiye/1710836/sule-cet-davasinda-gerekceli-karar-aciklandi.html 
Van Dijk, J. (2013). The Culture of Connectivity: A Critical History of Social Media. Oxford, UK: Oxford University Press. Yarar, N. (2016). Dijital aktivizm ve dijital eylem repertuvarı tipolojisi. In N. Timisi (Ed.), Dijital Kavramlar, Olanaklar, Deneyimler (pp. 215-247). İstanbul, Turkey: Kalkedon Yayınları.

Yargının çarkını yine toplum çevirdi. (2019, November 21). Memurlar.net. Retrieved from https://www.memurlar. net/haber/868421/yarginin-carkini-yine-toplum-cevirdi.html

Yegen, C. (2013). Demokratik ve yeni bir kamusal alan olarak sosyal medya. ANEMON Muş Alparslan Üniversitesi Sosyal Bilimler Dergisi, 1(2), 119-135.

YMK4 (2019). Yeni Medya Çalışmaları IV. Ulusal Kongre Genel Değerlendirme ve Sonuç Bildirgesi. Retrieved from http://yenimedya.org.tr/content/kongre-sonu\%C3\%A7-bildirgesi 


\section{EKLER}

\section{EK 1: Kodlama Cetveli}

İçerik analizinde kodlamalar Excel'e aşağıdaki kategorilerde 1 ve 0 şeklinde kodlanmıştır.

\section{Adalet Ana Kategorisi}

Adaletin Tesisi

Adaletsizlik Vurgusu

Adalet Umudu

Adalet

Çağrısı

Diğer

\section{Şule Çet Davası ve Bağlantılı Konular Ana Kategorisi}

Şule Çet Davası

Bağlantılı Konular

Diğer

\section{Bağlantılı Konular Ana Kategorisi}

Kadın Cinayeti

Kadına Yönelik Şiddet

Cinsel İstismar

Çocuk Cinayeti

Çocuk İstismarı

Kaybolan Şahıslar

Erkek Cinayeti

\section{Kamu Desteği Talebi}

Var

Yok 


\section{EK 2: Tutarlılık Oranı Hesaplaması}

Çalışmada analiz edilen 783 tweet, iki araştırmacı tarafından tümüyle incelenerek kategoriler oluşturulmuştur. 783 tweet bu kategorilere, 1. kodlayıcı tarafından kodlanmıştır. Sonrasında 31 Aralık 2019 tarihinden geriye doğru 100 tweet 2. kodlayıcı tarafından, tekrardan ve ayrıca kodlanmış ve iki kodlayıcı arasındaki tutarlııı payı aşağıdaki formüllere göre hesaplanmıştır.

Tutarlıllk yüzdesi $=\frac{\text { Kodlama } 1 / \text { Toplam Kodlama } 1}{\text { Kodlama } 2 / \text { Toplam Kodlama } 2} * 100$

ya da

Tutarllllk yüzdesi $=\frac{\text { Kodlama } 2 / \text { Toplam Kodlama } 2}{\text { Kodlama } 1 / \text { Toplam Kodlama } 1} * 100$ 


\section{TABLOLAR VE ŞEKILLER}

Tablo 1: Kodlayıcılar Arasındaki Tutarlılık/Yanılma Payı Oranları

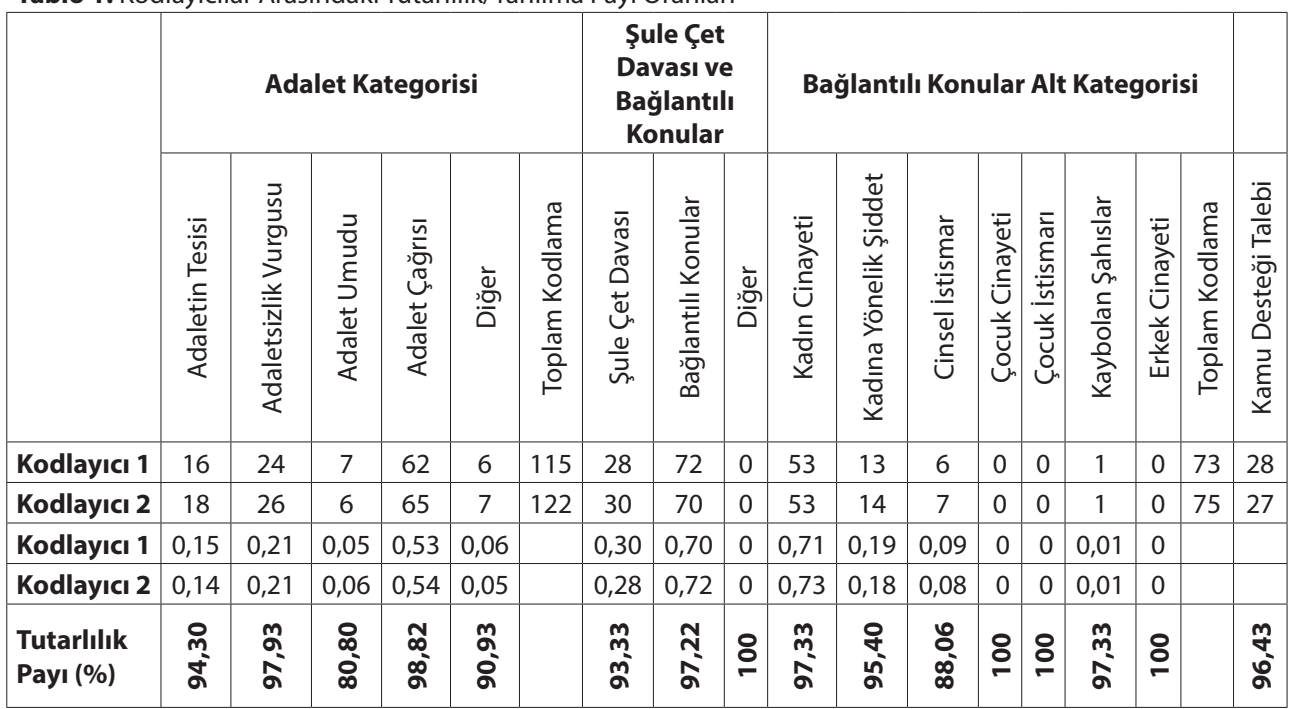

Şekil 1: 1 Şubat 2019-31 Aralık 2019 tarihleri arasında atılan tweet sayısı TARIHLERE GÖRE ATILAN TWEET SAYISI

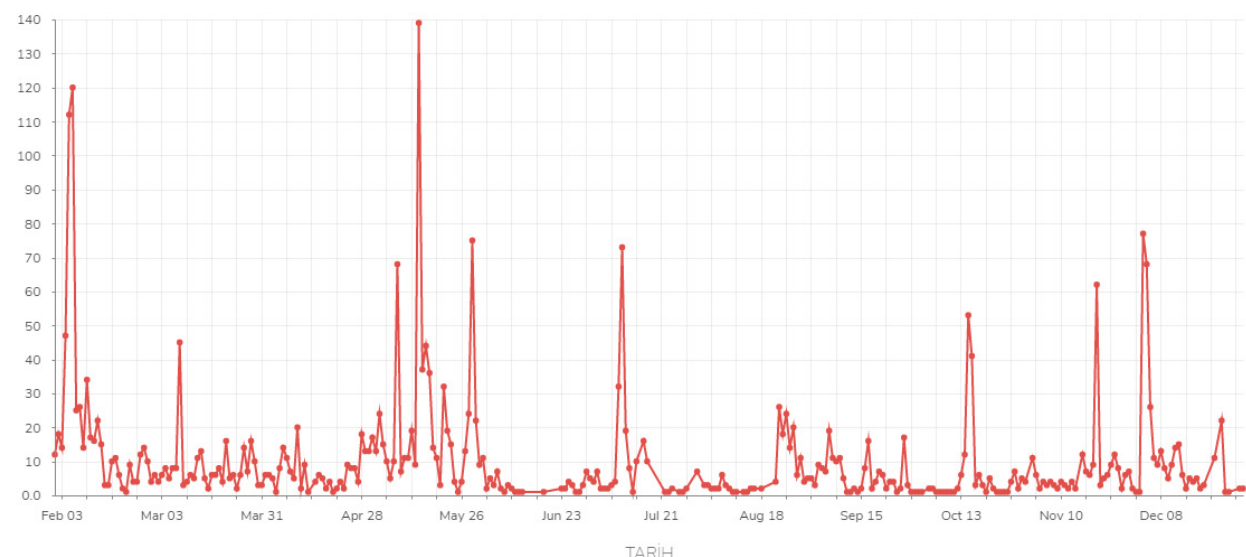


Şekil 2: 1 Şubat 2019 - 31 Aralık 2019 Tarihleri Arasında Atılan Tweetlere Yapılan Favlar TARIHE GÖRE FAVORI SAYISI

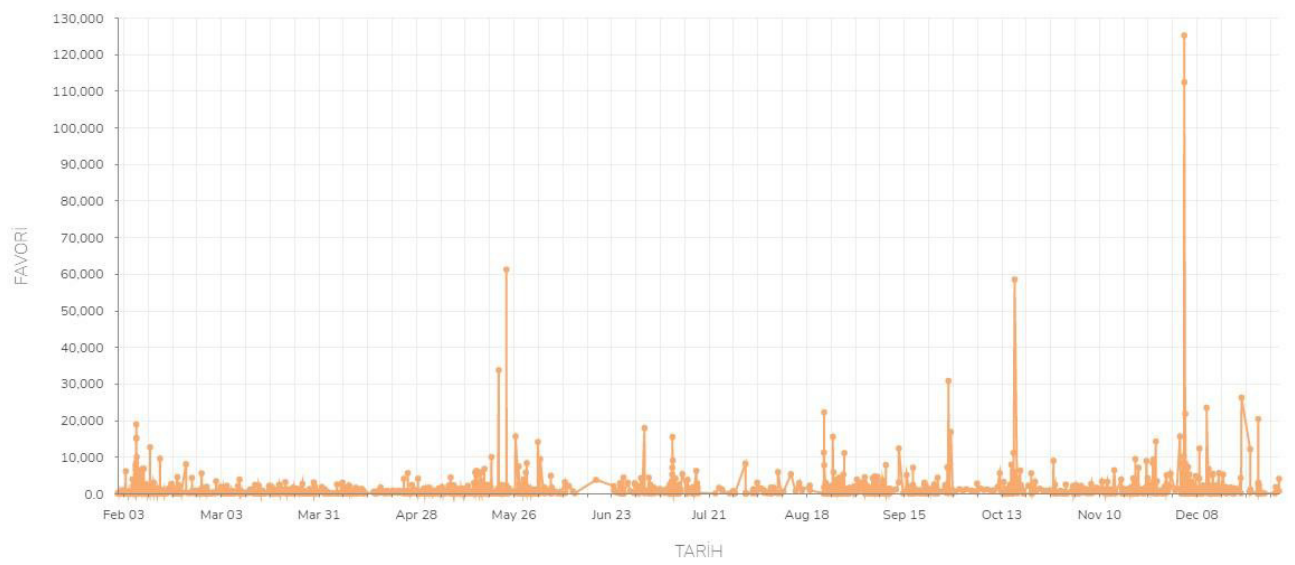

Şekil 3: Tweetlerin 'Şule Çet Davası' ve 'Bağlantılı Konular'a Göre Dağılımı

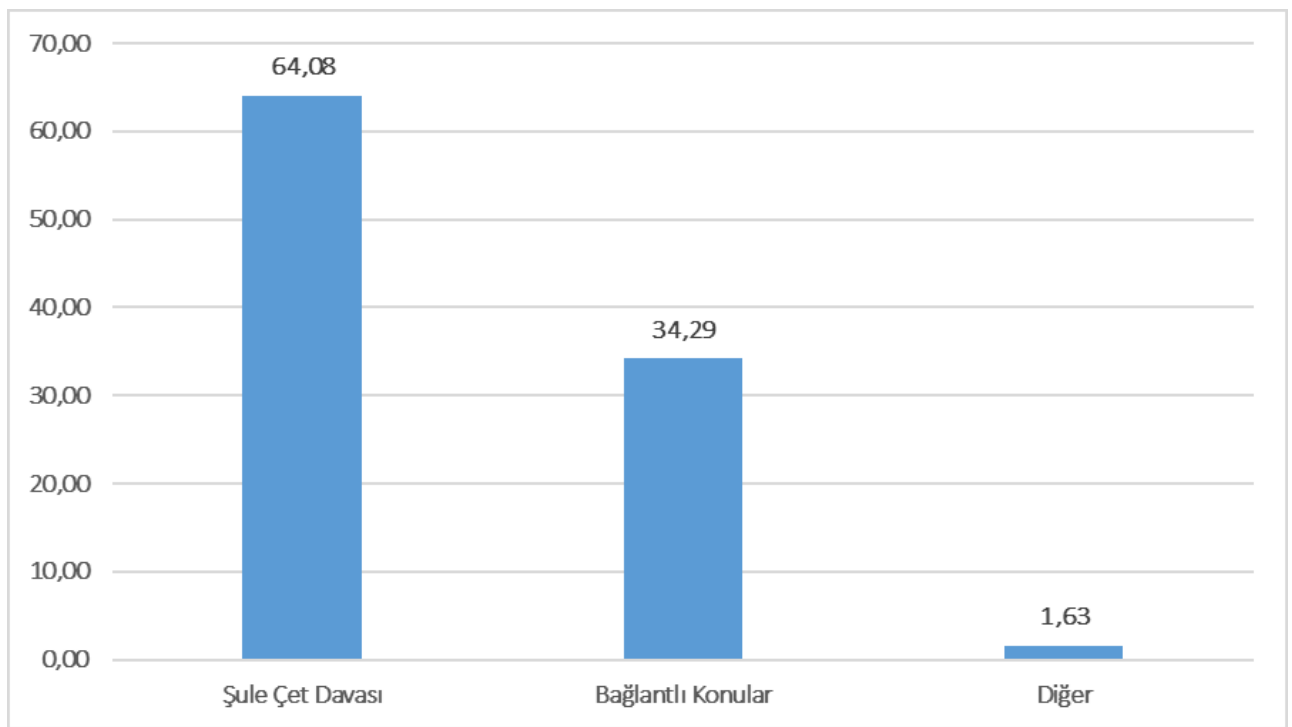


Şekil 4: Adaletle İlişkili Tweet'lerin Oranı

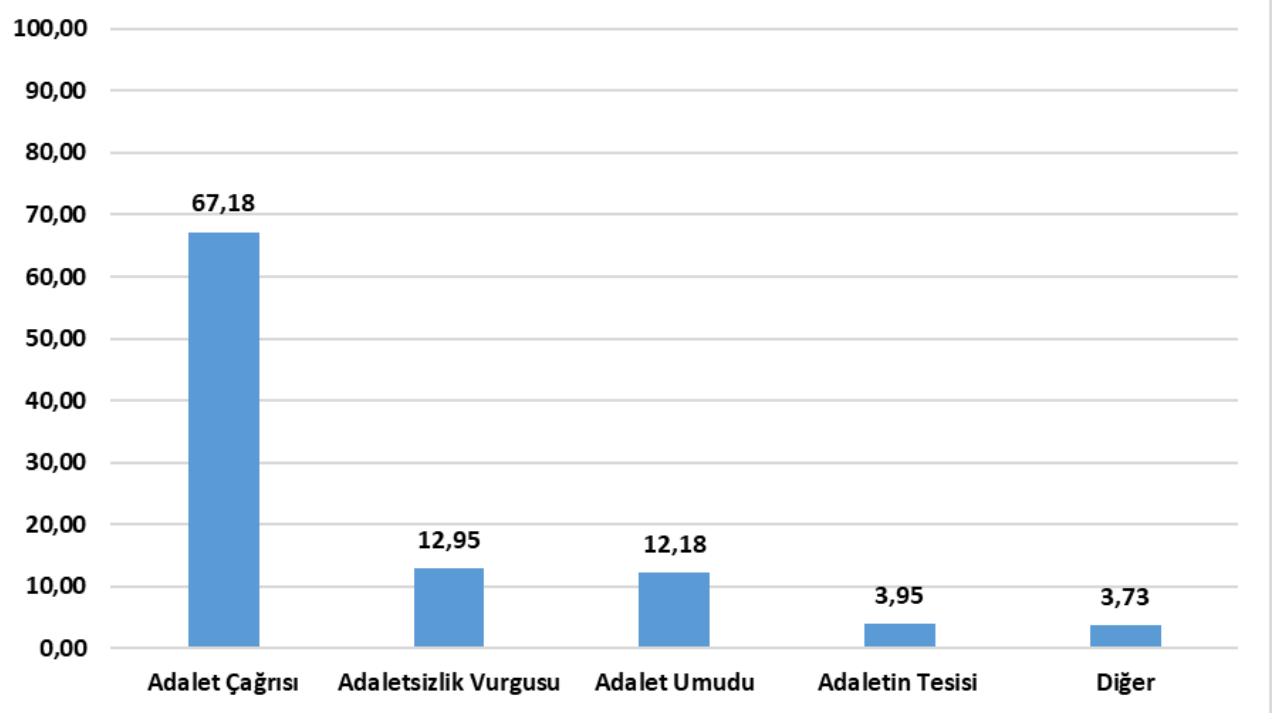

Şekil 5: Şule Çet ile İlgili Tweet'lerde Adalet Kavramı

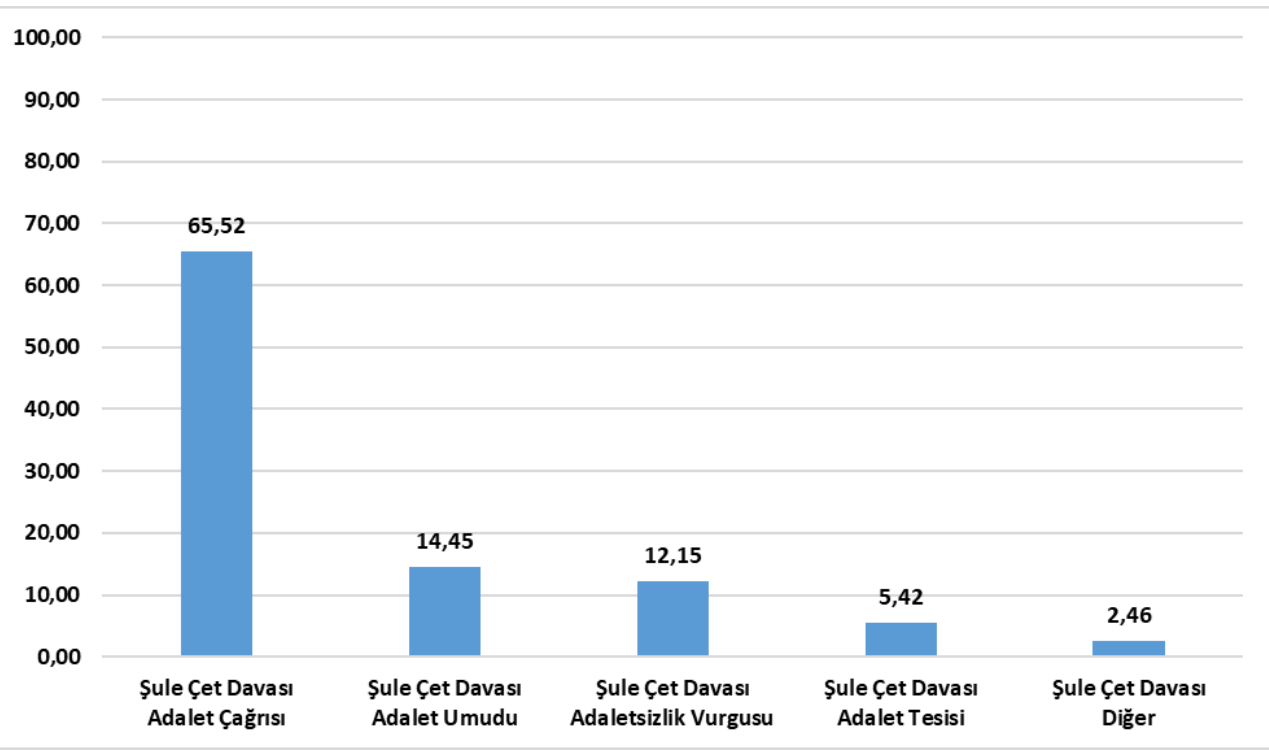


Şekil 6: Şule Çet Davası ile 'Bağlantılı Konular'a Illişkin Oranlar

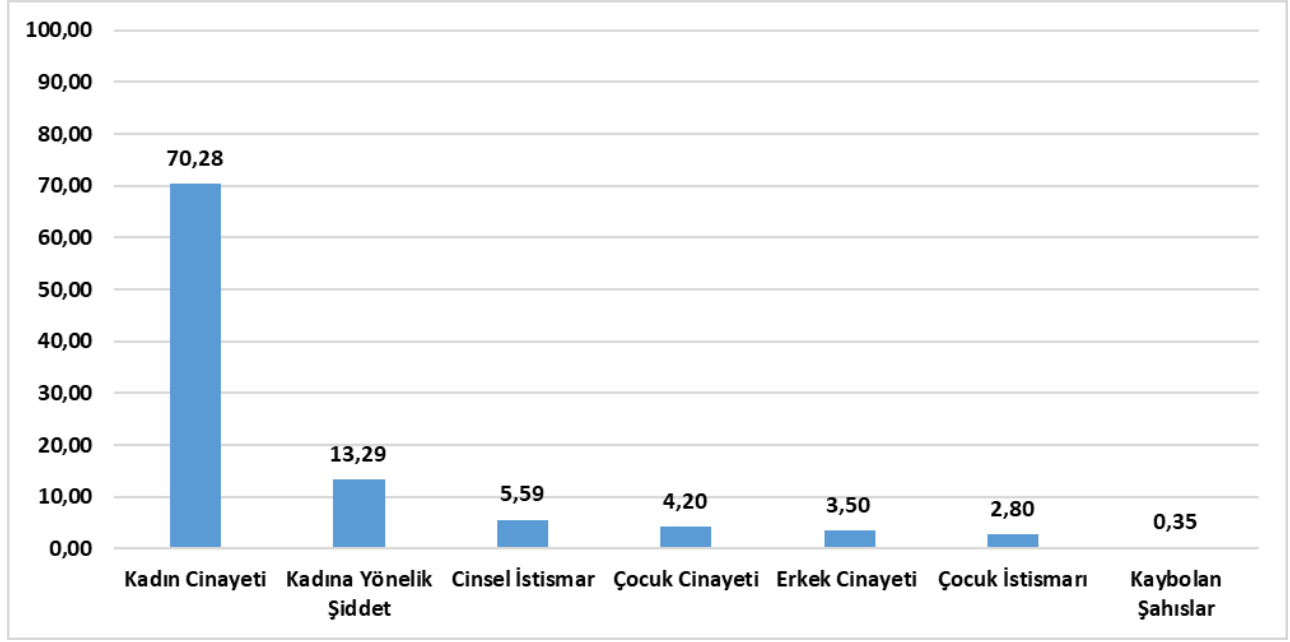

Görsel 1: \#Şuleçetiçinadalet Etiketinde En Fazla Tekrar Edilen Sözcükler

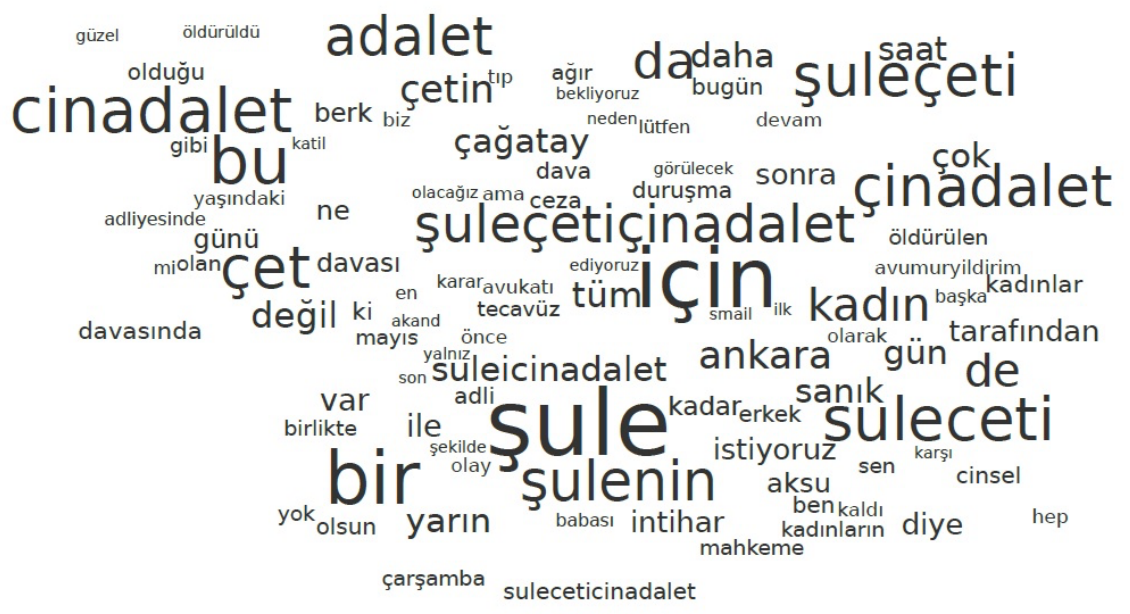




\section{SON NOTLAR}

- Fav, Twitterda favorite (favori)'nin kısaltılmış şekli olarak aynı anlamda kullanılmaktadır. Favlamak eylemi ise bir gönderinin beğenilerek favorilere eklendiği anlamına gelmektedir (Sepetçi, 2017, p. 27).

- Görsel 1'de yer alan kelime bulutu Workbench programı kullanılarak hazırlanmıştır. 